\title{
TENDÊNCIAS REGIONAIS DA INDÚSTRIA BRASILEIRA NO SÉCULO XXI
}

Clélio Campolina Diniz Philipe Scherrer Mendes
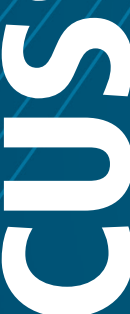

$\boldsymbol{n}$

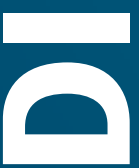

$\frac{1}{a}$

$\frac{0}{1}$

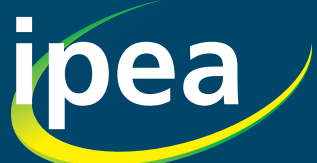





\section{TEXTO PARA DISCUSSÃO}

Rio de Janeiro, abril de 2021

\section{TENDÊNCIAS REGIONAIS DA INDÚSTRIA BRASILEIRA NO SÉCULO XXI'}

Clélio Campolina Diniz²

Philipe Scherrer Mendes ${ }^{3}$

1. Trabalho elaborado com apoio do Ipea, chamada pública oㅜ 58/2019.

2. Professor emérito do Centro de Desenvolvimento e Planejamento Regional (Cedeplar) da Universidade Federal de Minas Gerais ((UFMG); e pesquisador associado ao Programa Nacional de Pesquisa para o Desenvolvimento (PNPD) do Ipea. 3. Pesquisador visitante do Cedeplar/UFMG; e pesquisador associado ao PNPD//pea. 


\section{Governo Federal}

Ministério da Economia

Ministro Paulo Guedes

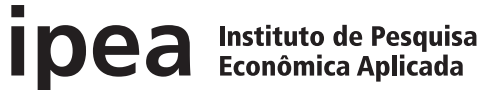

Fundação pública vinculada ao Ministério da Economia, o Ipea fornece suporte técnico e institucional às ações governamentais - possibilitando a formulação de inúmeras políticas públicas e programas de desenvolvimento brasileiros - e disponibiliza, para a sociedade, pesquisas e estudos realizados por seus técnicos.

Presidente

Carlos von Doellinger

Diretor de Desenvolvimento Institucional Manoel Rodrigues Junior

Diretora de Estudos e Políticas do Estado, das Instituições e da Democracia

Flávia de Holanda Schmidt

Diretor de Estudos e Políticas Macroeconômicas José Ronaldo de Castro Souza Júnior

Diretor de Estudos e Políticas Regionais, Urbanas e Ambientais

Nilo Luiz Saccaro Júnior

Diretor de Estudos e Políticas Setoriais de Inovação e Infraestrutura

André Tortato Rauen

Diretora de Estudos e Políticas Sociais

Lenita Maria Turchi

Diretor de Estudos e Relações Econômicas e

Políticas Internacionais

Ivan Tiago Machado Oliveira

Assessor-chefe de Imprensa e Comunicação André Reis Diniz

Ouvidoria: http://www.ipea.gov.br/ouvidoria

URL: http://www.ipea.gov.br

\section{Texto para Discussão}

Publicação seriada que divulga resultados de estudos e pesquisas em desenvolvimento pelo Ipea com o objetivo de fomentar o debate e oferecer subsídios à formulação e avaliação de políticas públicas.

(C) Instituto de Pesquisa Econômica Aplicada - ipea 2021

Texto para discussão / Instituto de Pesquisa Econômica Aplicada.- Brasília : Rio de Janeiro : Ipea , 1990-

ISSN 1415-4765

1.Brasil. 2.Aspectos Econômicos. 3.Aspectos Sociais. I. Instituto de Pesquisa Econômica Aplicada.

CDD 330.908

As publicações do Ipea estão disponíveis para download gratuito nos formatos PDF (todas) e EPUB (livros e periódicos). Acesse: http://www.ipea.gov.br/portal/publicacoes

As opiniões emitidas nesta publicação são de exclusiva e inteira responsabilidade dos autores, não exprimindo, necessariamente, o ponto de vista do Instituto de Pesquisa Econômica Aplicada ou do Ministério da Economia.

É permitida a reprodução deste texto e dos dados nele contidos, desde que citada a fonte. Reproduções para fins comerciais são proibidas.
JEL: 014; 018; R11; R58

DOI: http://dx.doi.org/10.38116/td2640. 


\section{SUMÁRIO}

SINOPSE

ABSTRACT

1 INTRODUÇÃO 7

2 CRITÉRIO DE REGIONALIZAÇÃO E BASE EMPÍRICA

3 TENDÊNCIAS REGIONAIS DA INDÚSTRIA BRASILEIRA NO SÉCULO XXI 12

4 SÍNTESE DO DESENVOLVIMENTO REGIONAL RECENTE.

5 DESAFIOS PARA AS POLÍTICAS REGIONAIS E INDUSTRIAIS NO BRASIL 32

REFERÊNCIAS 37

BIBLIOGRAFIA COMPLEMENTAR

ANEXO 



\section{SINOPSE}

O objetivo deste trabalho é atualizar o diagnóstico sobre as tendências recentes do padrão locacional da indústria no território. Considerando-se a retomada do crescimento econômico e industrial no século XXI, as mudanças estruturais em curso e seus efeitos nos processos de industrialização, desindustrialização e padrão locacional da indústria, torna-se necessário uma reavaliaçấo dos resultados recentes e suas tendências, especialmente seus impactos regionais. Entre essas mudanças estruturais, destacam-se as transformaçôes no cenário internacional; o acelerado processo de mudanças tecnológicas e organizacionais; o aumento do peso dos serviços na ocupação e na renda; o dinamismo da fronteira agropecuária; as mudanças nas políticas públicas; os investimentos em infraestrutura, principalmente relacionados ao setor energético; e a adoção de políticas sociais de natureza horizontal. Tudo isso diante de um grave processo de desindustrialização do país.

Palavras-chave: industrialização; desindustrialização; padrão locacional da indústria; desenvolvimento regional.

\section{ABSTRACT}

Throughout this article, we analyze and discuss the main trends in recent locational patterns of Brazilian industry. Taking into account the overall economic growth as well as in the industry sector since the beginning of XXI century, many structural changes related to the occurrence of simultaneous process like industrialization and deindustrialization are worth of analyzing. In fact, to understand the new changes in locational patterns of industry activities, we claimed here that it will be required to recognize among others: accelerated rhythms of technical and organizational changes; the increasing share of service sector in the economy; the dynamics of agricultural frontiers; the impact of public policies especially those from social policies; and the results of investments in infrastructure driven for energetic purposes.

Keywords: industrialization; deindustrialization; industry locational patterns; regional development. 



\section{INTRODUÇÃO}

A indústria manufatureira no Brasil nasceu de forma tímida e dispersa, mais de um século após sua origem nos países centrais. Sua expansão somente ocorreu a partir do final do século XIX e se concentrou no estado de São Paulo, especialmente em sua capital e atual área metropolitana. Em 1970, considerado o pico da concentração regional da indústria no Brasil, $58 \%$ da produção nacional estava no estado de São Paulo, sendo $75 \%$ em sua região metropolitana (RM). Esse fenômeno encontra-se exaustivamente analisado por vários autores, com destaque para Castro (1971), Dean (1971), Silva (1976) e Cano (1976).

Após o ciclo expansivo da indústria brasileira no pós-Segunda Guerra Mundial, com forte concentração na área metropolitana de São Paulo, vários fatores atuaram no sentido da desconcentração territorial. Pela lógica do mercado, no sentido da desconcentração, destacam-se: i) geração de deseconomias de aglomeração na RM de São Paulo; ii) expansão e melhoria da infraestrutura em outras regióes do país; iii) crescimento urbano generalizado; e iv) movimentos das fronteiras agropecuária e mineral em direção ao Centro-Oeste e Norte do país e seus possíveis efeitos sobre o crescimento populacional, urbano e industrial, gerando novas centralidades. Um segundo grupo de fatores estaria relacionado com decisóes governamentais, a nível federal e dos estados, com destaque para: i) transferência da capital para Brasília e a integração do mercado nacional com a construção dos grandes eixos viário; ii) incentivos fiscais para o Nordeste e para a Zona Franca de Manaus; e iii) "guerra fiscal" entre os estados na atração de investimentos.

De acordo com Diniz (1978; 1981), ainda na década de 1970, no auge da expansão industrial do Brasil, o estado de São Paulo iria perder participação relativa na produção industrial brasileira. Isto porque, aquele estado, que detinha $58 \%$ da produção industrial do país, vinha perdendo participação nas decisões de investimento, vendo-as se reduzir continuamente ao longo da década de 1970, até chegar a 17,6\% do total nacional em 1979 (Diniz, 1981, p. 231). ${ }^{1}$

1. No auge do governo militar qualquer investimento industrial para receber financiamento ou apoio oficial teria que ter seu projeto aprovado pela Comissão de Desenvolvimento Industrial (CDI) do Ministério da Indústria e Comércio. 
Essa análise estava fundamentada no entendimento de que havia uma defasagem temporal entre decisóes e materialização de investimentos e entre estes e os resultados produtivos, como está teoricamente demonstrado em Kalecki (1973). Nessa mesma linha, Diniz e Lemos (1986) indicavam as mudanças no padrão regional brasileiro, o que só viria a ser empiricamente comprovado mais tarde, após a divulgação dos resultados dos censos industrial e agrícola de 1980 e das contas nacionais, quando ficou comprovado que o estado de São Paulo estava perdendo participação relativa não só nas produções industrial e agrícola como também na renda nacional.

A partir de então estabeleceu-se certa controvérsia interpretativa do fenômeno da desconcentração econômica, especialmente industrial. Alguns autores defendiam a visão de contínua concentração no estado de São Paulo (Storper, 1991; Azzoni, 1986; Townroe e Keen, 1984), sem diferenciar as dinâmicas da área metropolitana e do interior do estado. Superando os critérios de divisão territorial até então utilizados em macrorregiôes e estados federados, Diniz (1993) e Diniz e Crocco (1996) propuseram um critério de regionalizaçáo alternativo. Tomaram o recorte das microrregiôes geográficos do Instituto Brasileiro de Geografia e Estatística (IBGE) e denominaram aglomerações industriais relevantes (AIRs) aquelas microrregióes geográficas com mais de 10 mil empregos industriais, as quais representavam $86 \%$ do emprego industrial total.

Baseados nesses critérios, concluíram que estaria havendo uma contínua mudança no padrão locacional da indústria no Brasil. Embora estivesse havendo crescimento industrial e formaçáo de novas aglomeraçôes produtivas em todas as regiōes do país, havia uma predominância de crescimento no "polígono industrial" (Diniz, 1993), que combinava a desconcentração da RM de São Paulo com a localização e expansão de novos centros industriais na grande área formada dentro do polígono Belo Horizonte-Uberlândia-Londrina-Porto Alegre-Florianópolis-Belo Horizonte, incluído o próprio interior do estado de Sáo Paulo.

Como se tratava de um fenômeno dinâmico, os autores observaram a necessidade de se avaliar as novas tendências a partir de várias transformaçôes e movimentos em curso, entre os quais, aqueles que poderiam fortalecer a expansão dentro do polígono, a saber: i) expansão e consolidação do Mercado Comum do Sul (Mercosul) e seus possíveis impactos sobre o crescimento industrial nos estados do Sul do país; ii) mudanças tecnológicas e fortalecimento dos centros industriais mais desenvolvidos; iii) maior concentração do mercado de trabalho especializado; e iv) alta concentração regional da renda e da demanda. 
No auge do crescimento industrial ampliou-se também a disputa entre os estados na atração de investimentos. Nessa chamada guerra fiscal eram e ainda são utilizados diferentes mecanismos de isenções fiscais, oferta de terrenos e infraestrutura e, inclusive, participação acionária nos novos investimentos (Vieira, 2014). Esses incentivos foram preferentemente concedidos a empresas estrangeiras, especialmente automotivas. Observa-se que essa guerra fiscal é extremamente danosa do ponto de vista econômico, social e político, por desviar preços relativos a favor de bens não prioritários, comprometer as finanças públicas, prejudicar o capital nacional e concorrer com a política regional oficial. Nesse sentido, a ausência de articulação entre o governo federal e os governos estaduais influencia a distribuição territorial da indústria de transformação brasileira, com tendência a beneficiar regiốes com maior capacidade de renúncia fiscal.

Posteriormente, vários trabalhos foram desenvolvidos, analisando o fenômeno da desconcentração industrial no país, a maioria indicando que além do crescimento industrial no chamado "polígono" estaria havendo crescimento industrial nas regiôes Norte, Nordeste e Centro-Oeste, além do próprio polo de Manaus. Entre esses, destacam-se Negri (1994), Pacheco (1999), Andrade e Serra (2000), Saboia (2001; 2013), Mendes, Hermeto e Britto (2019).

Considerando-se a retomada do crescimento econômico e industrial no século XXI, as mudanças estruturais em curso e seus efeitos nos processos de industrializaçáo, desindustrialização e padrão locacional da indústria, torna-se necessário uma reavaliação dos resultados recentes e suas tendências, especialmente quanto a seus impactos regionais.

Entre essas mudanças estruturais, destacam-se as mudanças no cenário internacional; o acelerado processo de mudanças tecnológicas e organizacionais; o aumento do peso dos serviços na ocupação e na renda; o dinamismo da fronteira agropecuária; as mudanças nas políticas públicas; os investimentos em infraestrutura, principalmente relacionados ao setor energético; e a adoção de políticas sociais de natureza horizontal. Tudo isso diante de um grave processo de desindustrialização do país.

Além de compreender melhor as tendências recentes, esta análise poderá contribuir para se repensar e adequar as políticas regionais de desenvolvimento e as distorçôes provocadas pelos atuais sistemas federativo e tributário. Nesse sentido, vários trabalhos vêm sendo elaborados para se discutir diferentes dimensôes do desenvolvimento regional 
e da busca de se construir uma agenda de trabalho que seja capaz de fundamentar as mudanças e a formatação de uma nova política regional para o Brasil.

\section{CRITÉRIO DE REGIONALIZAÇÃO E BASE EMPÍRICA}

Sabe-se que as regiốes não são estáticas pois a dinâmica econômica e social tem impacto diferenciado sobre o território, em função da distribuição da população, da rede urbana, das atividades econômicas, da infraestrutura e do impacto disso tudo sobre o meio natural. Nesse sentido, o IBGE vem atualizando as regionalizaçôes do país, considerando também os recortes político-administrativos em razão da criação de estados federados e municípios. Nesse sentido, há uma diversidade de regionalizaçóes nas análises brasileiras sobre o fenômeno regional, seja por opção teórica e metodológica, seja por respeito às divisões político-administrativas do país, seja pela existência das regionalizaçôes oficiais estabelecidas pelo IBGE ou da própria organização das informações estatísticas.

Para os propósitos deste trabalho, entende-se que o recorte das microrregióes geográficas permite uma análise adequada dos padróes locacionais da indústria e suas tendências no Brasil. A utilização das microrregiôes permite também sua agregação por estados, macrorregiôes ou por outras formas de integração naquelas regiōes de maior densidade industrial.

As divisóes convencionalmente utilizadas em macrorregiôes, mesorregiôes, regióes intermediárias, estados federados ou municípios apresentam várias dificuldades e inconvenientes. As quatro primeiras, por serem muito amplas e heterogêneas, dificultando observar as tendências e as características estruturais das aglomeraçóes industriais, pois estas tendem a se concentrar em espaços ou aglomeraçôes de menor escala, em geral nas cidades ou centros urbanos. A divisão por municípios tem o efeito oposto, por sua excessiva pulverização e porque muitas aglomeraçôes reúnem mais de um ou vários municípios, a exemplo das grandes áreas metropolitanas.

Mais do que permitir a agregação das microrregiōes por estados, macrorregiôes, ou regiôes intermediárias, a divisão por microrregiōes possibilita recortes adicionais quando se observa a contiguidade de mais de uma AIR. Nesse sentido, a partir das observaçóes empíricas serão feitos recortes adicionais para se identificar a formaçáo de

aglomeraçóes ampliadas. De maneira inversa, para as regiốes Centro-Oeste e Norte do 
país, com maior dispersão e tamanho geográfico das microrregiōes, serão feitos recortes para a escala municipal e em especial para as cidades que exercem as centralidades industrial e econômica.

Além dos aglomerados metropolitanos compostos por mais de uma ou várias AIRs, outras aglomeraçóes vêm formando eixos, corredores ou outras formas geográficas de integração produtiva. Nesses casos, por sua proximidade ou complementaridade, elas criam economias de aglomeração, estimulando a atração de novos investimentos.

Ressalte-se que qualquer que seja o recorte utilizado há dificuldades com a base empírica, segundo as diferentes fontes utilizadas como indicadores das atividades industriais. Por isso, utilizaremos, de forma complementar, três bases de dados distintas, a saber: Relação Anual de Informações Sociais (Rais), Pesquisa Industrial Anual (PIA) e Secretaria de Comércio Exterior (Secex). A Rais é um registro anual de informaçóes de todo o mercado de trabalho formal, permitindo a identificação da atividade produtiva no nível local. Apesar da riqueza dos seus dados, que possibilitam a identificação de informações no nível do vínculo empregatício, ela não possui nenhuma outra informação sobre a atividade produtiva senão aquela especificamente associada ao registro do emprego. A PIA só divulga dados agregados, por Unidade da Federação (UF), dificultando a identificação do nível de produção de forma mais desagregada. Ela permite, no entanto, identificar o peso e evolução dos estados no Valor da Transformação Industrial (VTI). Igualmente, utilizaremos os dados da Secex, como indicador da participação de cada estado nas exportações de bens industriais.

Os dados agregados por estado permitem avaliar o peso de cada estado na produção e nas exportações industriais e as características da estrutura industrial de cada um. Esses elementos são importantes para a análise política da disputa federativa e suas implicaçóes políticas, inclusive para sua consideração em termos das políticas regionais propriamente ditas, da guerra fiscal e do sistema fiscal e tributário.

Além das informações quantitativas antes mencionadas, a realização deste artigo valeu-se também do conhecimento factual e qualitativo de vários especialistas e dos próprios autores sobre a realidade brasileira, inclusive com visitas a várias regióes e entrevistas com instituiçôes locais. 
Ressalte-se, por fim, que as mudanças estruturais e a crescente integração entre o que se classifica como indústria manufatureira e os serviços dificultam uma adequada mensuraçáo do desempenho setorial, exigindo uma nova classificação das atividades econômicas e a correspondente base empírica. Infelizmente, ainda não há uma classificação consensual na literatura.

\section{TENDÊNCIAS REGIONAIS DA INDÚSTRIA BRASILEIRA NO SÉCULO XXI}

\subsection{Antecedentes}

Entre 1970 e 1980, período de crescimento industrial acelerado, o número de AIRs subiu de 33 para 76, e o emprego industrial dobrou (Diniz e Crocco, 1996). No mesmo período, a participação da indústria manufatureira no produto interno bruto (PIB) subiu de 18\% para 25\% (Morceiro, 2018, p. 17).

$\mathrm{Na}$ década de 1980, apesar da forte e prolongada crise econômica, mas ainda carregando os efeitos residuais das decisóes de investimento anteriores, o número de AIRs subiu 76 para 90, com ligeiro aumento do emprego industrial e a participação da indústria no PIB chegou a 26\% em 1985 (Morceiro, 2018, p. 17).

Na década de 1990, embora o número de AIRs ainda tenha subido de 90 para 98, houve redução no emprego, seja pelo período de instabilidade econômica, via crises inflacionárias, seja pela abertura comercial, que impactou negativamente a atividade industrial, seja, ainda, pela aceleração do processo de desindustrializaçáo. No período, a participação da manufatura no PIB foi reduzida drasticamente. ${ }^{2}$ Além da crise, as mudanças estruturais da economia e dos processos de trabalho provocaram uma relativa perda da indústria manufatureira na ocupação, tanto pelos processos de desindustrialização como pelo fenômeno da terciarização. Em termos ocupacionais, houve mudança na estratégia de incorporação de parcela da mão de obra, vinculada a

2. Há grande dificuldade empírica e metodológica para a análise das décadas de 1980 a 2000 por causa das mudanças nas bases de dados, pelo processo inflacionário, por mudanças nos preços relativos e pelas mudanças estruturais que implicaram na transferência de várias atividades antes contabilizadas dentro do setor industrial para o setor serviços. Morceiro (2018) trabalhou exaustivamente esses temas, oferecendo uma série dos dados a preços correntes e constantes para o período 1947-2017. 
atividades auxiliares à produção. Isso implicou redução do efetivo de mão de obra, antes considerado industrial, e elevação do contingente, consequentemente, da participação do setor serviços. Além dessa redução, destaca-se o impacto causado pela perda de importância do setor industrial na atividade econômica nacional.

Em síntese, após o crescimento econômico, em geral, e industrial, em particular, generalizado durante o chamado "milagre econômico" da década de 1970, o país ingressou em forte crise econômica, dificultando a manutenção dos investimentos públicos e desestimulando os investimentos privados.

Adicionalmente, iniciou-se um sistemático processo de críticas ao sistema de incentivos fiscais para as regiōes menos desenvolvidas, especialmente para o Nordeste. No bojo da orientaçáo neoliberal e da cartilha do Consenso de Washington, ${ }^{3}$ as superintendências regionais - Superintendência do Desenvolvimento do Nordeste (Sudene), Superintendência do Desenvolvimento da Amazônia (Sudam) e Superintendência do Desenvolvimento do Centro-Oeste (Sudeco) - chegaram a ser extintas. Foram em seguida recriadas como agências de desenvolvimento, porém com seu prestígio reduzido. Nessas condiçôes, houve redução do crescimento e, consequentemente, da formação de novas áreas industriais.

\subsection{Desempenho no século XXI}

\subsubsection{0 contínuo declínio industrial das RMs de Rio de Janeiro e São Paulo}

No início da industrialização brasileira, embora relativamente dispersa, a maior parcela da produção se localizou no Rio de Janeiro. Em 1907, primeiro ano de apuração das estatísticas, a RM do Rio de Janeiro ainda participava com 38\% do total nacional (Cano, 1976). No entanto, desde então, vem perdendo posição relativa na produção industrial brasileira, chegando a menos de $10 \%$ do total nacional no final do século.

Entre as principais razóes para esse resultado, destacam-se o declínio da cafeicultura fluminense, a competição com São Paulo e com outras regiôes do país,

3. Consenso de Washington foi uma recomendação internacional elaborada em 1989 por economistas de instituições financeiras como o FMI, o Banco Mundial e o Departamento do Tesouro dos Estados Unidos, visando difundir a conduta econômica neoliberal. 
a debilidade de sua burguesia industrial, a perda de seu papel como centro financeiro do país, o esvaziamento político e a perda de centralidade com a transferência da capital para Brasília (Cano, 1976; Leopoldi, 2000; Lessa, 2000). Entre 2000 e 2018 a participação da RM do Rio de Janeiro no emprego industrial do país caiu de 4,8\% para $3,1 \%$. A participação do estado no VTI caiu de $7,9 \%$ para $7 \%$, porém a queda não foi maior por uma expansão, ainda que pequena, das áreas industriais fora da RM do Rio de Janeiro (Campos, Macaé, Regiāo Serrana, Vale do Paraíba).

Apesar disso, ainda havia uma grande expectativa de retomada do crescimento industrial no estado do Rio de Janeiro. A descoberta do pré-sal e as expectativas econômicas abriram uma avenida de novas possibilidades, com retomada da indústria naval, com ampliaçáo de estaleiros existentes e montagem de novos; com o megaprojeto petroquímico em Itaguaí (Complexo Petroquímico do Rio de Janeiro - Comperj), liderado pela Petrobrás e com previsão de vinte empresas privadas, com estimativa de investimento de US\$ 200 bilhôes e geração de mais de 200 mil empregos diretos e indiretos (Silva e Irazábal-Zurita, 2019) com o complexo portuário e industrial do Açu; a base aérea e marítima de suporte às atividades da Petrobrás, em Macaé; além da instalação de três montadoras automotivas no sul do estado (Resende e Porto Real).

Havia a expectativa de que o sucesso desses projetos pudesse exercer um papel motriz, induzindo a criaçáo de indústrias complementares. No entanto, com a operação Lava-jato e a crise política no governo e na Petrobras, o projeto Comperj foi abandonado, os investimentos foram paralisados, trazendo grande frustação das expectativas alimentadas sobre o desenvolvimento de uma das regiôes mais pobres e atrasadas do Brasil, a Baixada Fluminense (Silva e Irazábal-Zurita, 2019). O projeto do Açu sofreu o impacto da crise que atingiu o grupo EBX e, hoje, apesar de estar sob o controle de novo grupo empresarial, encontra-se dependente da situaçáo geral da economia brasileira, das novas orientaçóes políticas da Petrobras e do governo federal.

Diferentemente da RM do Rio de Janeiro, e apesar da continua perda de peso na produção industrial brasileira nas últimas décadas, a RM de São Paulo náo enfrentou o fenômeno clássico da desindustrialização, como ocorreu no nordeste dos Estados Unidos e noroeste da Inglaterra. Nessas regiôes, a crise da indústria foi seguida da perda em todas as outras atividades, com alto desemprego e fortes processos migratórios (Bluestone e Harrison, 1982; Massey e Meegan, 1982; Peet, 1983). 
Ao contrário, a cidade de São Paulo, embora tenha perdido participação na produção industrial e na renda nacional, reforçou seu papel como centro financeiro (bancos, corretoras, bolsas de açôes, de títulos e mercadorias), com sedes empresariais, atividades comerciais, serviços educacionais, de pesquisa, consultoria, medicina avançada, atividades culturais e de lazer e outros serviços de apoio aos negócios e ao lazer (hotéis, restaurantes, teatros etc.). Manteve também os dois mais importantes aeroportos do país, doméstico e internacional. Nesse sentido, Diniz e Campolina (2007) ressaltaram o papel da área metropolitana estendida, composta especialmente pelo eixo Campinas-São Paulo-São José dos Campos, onde estão indústrias de grande sofisticação tecnológica, boas universidades e instituiçôes de pesquisa que reafirmam o papel de São Paulo como cidade primaz do Brasil e elo de integração com a rede de metrópoles mundiais.

A orientação do governo de São Paulo em fortalecer a infraestrutura do chamado vetor perimetral Sorocaba-Campinas-São José dos Campos-Porto de São Sebastião, composto por seis segmentos de integração entre si, denominando-o Plano Macrometrópole Paulista (Proença e Santos Junior, 2019). Nessa regiấo, incluída a cidade de São Paulo, está localizado o mais denso meio técnico-científico-informacional do Brasil. Nele está a base industrial mais moderna e integrada do Brasil, com as maiores e melhores universidades do país - Universidade de São Paulo (USP), Universidade Estadual de Campinas (Unicamp), Universidade Federal de São Paulo (Unifesp), entre outras -, instituiçôes de pesquisa, melhor rede de infraestrutura e de serviços modernos.

Mendes, Hermeto e Britto (2019) identificam que, apesar de se perceber melhoria na distribuição do emprego industrial no território nacional, entre 2008 e 2014 observou-se o reforço da concentração dos trabalhadores com maior grau de instrução (mestres e doutores) e aumento da concentração da indústria de mais elevada intensidade tecnológica em São Paulo e seu entorno. Adicionalmente, a elevaçáo dos custos nessa regiáo promoveu o deslocamento de atividades com menor intensidade tecnológica e produtividade para as regiôes com menores custos, especialmente para o Nordeste.

Ressalte-se que a megaconcentração metropolitana no Brasil, conjugada com a má distribuição da renda e a precariedade da infraestrutura, cria diferentes disfuncionalidades. Isso ocorre não só pelo aumento dos custos diretos e indiretos como também pela forte desigualdade social induzida por essa concentração, que produz evidências como deficit habitacional, precariedade do sistema sanitário, baixa qualidade do sistema de transporte 
pública, aumento dos conflitos sociais, do crime organizado, não apenas em São Paulo, também na maioria das metrópoles brasileiras (Diniz e Vieira, 2016).

\subsubsection{Consolidação e alargamento do polígono industrial}

\section{Criação de novas AIRs e sua localização}

A retomada do crescimento econômico a partir da década de 2000, articulado a outros fatores, elevou o número de AIRs de 98, em 2000, para 144 em 2010. Em 2015, o número de passou a 151, tendo retornado a 149, em 2018. Vale destacar que essa variação no número de AIRs entre os anos não significa diretamente o crescimento ou a redução expressa pela diferença. Para ilustrar, entre 2015 e 2018 cinco novas AIRs surgiram, enquanto três que estavam presentes em 2015 não possuíam, em 2018, 10 mil postos de trabalho. O crescimento foi relativamente alto e sustentado até 2013, com o emprego industrial chegando a 7,9 milhóes, quando o número de AIRs atingiu 154 e chegou a 156 em 2014, embora o número de postos de trabalho tenha sido menor que em 2013. A partir de entáo, a crise econômica desestimulou o crescimento e as decisões de investimento. Houve instabilidade, com algumas AIRs crescendo e outras perdendo tamanho. O nível de emprego subiu para 6,4 milhóes em 2015, caindo para 5,6 milhóes em 2018, para o conjunto das AIRs.

O mapa 1 e a tabela A.1, do anexo, apresentam a distribuição espacial e a magnitude dessas aglomeraçôes industriais, indicando onde se deu o surgimento de novas ou o fortalecimento das já existentes. 
MAPA 1

Brasil: distribuição espacial das AIRs com mais de 10 mil empregos industriais (2000 e 2018) $1 \mathrm{~A}-2000$

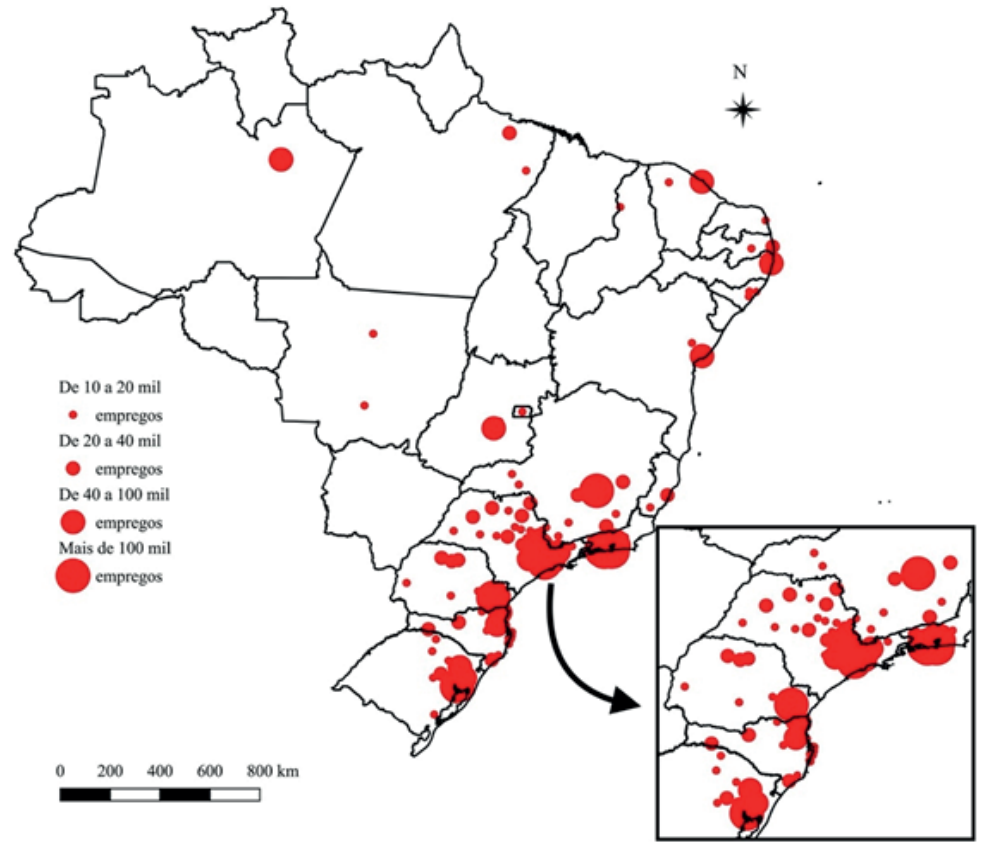

1B -2018

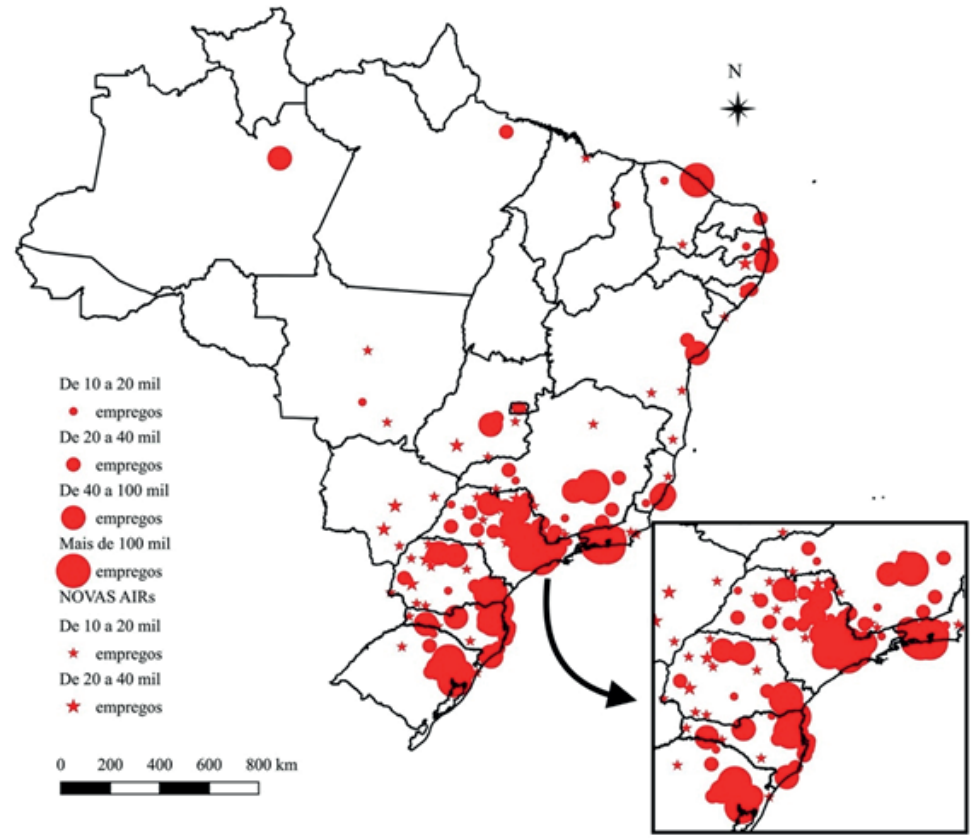

Fonte: Rais.

Elaboração dos autores.

Obs.: Figura cujos leiaute e textos não puderam ser padronizados e revisados em virtude das condições técnicas dos originais (nota do Editorial). 
A análise da distribuição regional dessas aglomerações mostra que, apesar das políticas de incentivos regionais e de decisóes políticas, não houve uma mudança macroespacial significativa da produção industrial no Brasil. O crescimento das últimas décadas combina a perda relativa das áreas metropolitanas primazes na produção industrial (Rio de Janeiro e São Paulo) com o adensamento industrial na região anteriormente caracterizada por Diniz (1993) como polígono industrial, cujos vértices são Belo Horizonte, Uberlândia, Londrina, Porto Alegre, Florianópolis, Belo Horizonte. Dentro desse polígono foram implantadas 31 das 52 novas AIRs criadas entre 2000 e 2018. Nessa ampla região estão também as atividades industriais de tecnologia mais sofisticada, com maiores escalas e maior capacidade de integração e multiplicação, a exemplo das indústrias metalmecânicas, elétricas, eletrônicas e químicas.

Adicionalmente, essa ampla área industrial foi alargada com a criação de várias aglomeraçóes industriais no oeste dos estados de Santa Catarina, Paraná, São Paulo e Minas Gerais. Essas novas aglomeraçôes estão predominantemente nos setores agroindustriais (açúcar, frigorífico, beneficiamento de cerais, alimentos industrializados em geral, insumos agropecuários etc.). Seguindo o mesmo padrão, foram criadas três AIRs no sudoeste do Mato Grosso do Sul (Três Lagoas, Dourados e Iguatemi) e uma no sudoeste de Goiás (Rio Verde), próximas e em padrão semelhante à agroindústria do oeste dos estados do Paraná e São Paulo. Outra foi localizada no sudeste de Goiás (Cataláo), em atividades automotriz, equipamentos e insumos agrícolas (Mitsubshi, Johnn Deer, adubos).

A nosso ver, essas cinco microrregióes podem também ser entendidas como alargamento da área industrial mais densa e consolidada do país, acompanhando a fronteira agropecuária que se desloca para o Centro-Oeste. Portanto, 36 das 51 novas AIRs se localizaram dentro ou como extensão dessa área. A estas poder-se-ia acrescentar as AIRs de Goiânia e Anápolis, por sua estrutura diversificada, sua proximidade à regiâo de industrialização mais densa e diversificada do país e seu crescimento recente. Em Anápolis, por exemplo, está havendo grande expansão de unidades de produção farmacêutica e ainda foram instalados a montadora Hyundai e um porto seco, além dos possíveis efeitos da base aérea local.

Deve-se acrescentar também a expansão da AIR de Volta Redonda, não pelo seu núcleo original (Cia. Siderúrgica Nacional), mas pela instalaçáo de unidades 
automotrizes em Resende e Porto Real (Volkswagen e Peugeot), próximas às áreas industriais do Vale do Paraíba Paulista (Taubaté e São José dos Campos) e, portanto, com possibilidade de se integrar a elas.

O que e percebe é o alargamento do antigo polígono industrial, formando um novo polígono cujos vértices são Belo Horizonte, Anápolis, Rio Verde, Campo Grande, Foz do Iguaçu, Santa Cruz do Sul, Porto Alegre, Florianópolis, Volta Redonda, Belo Horizonte.

Ao contrário da previsão feita por Diniz (1993), a integração econômica com os demais países da América Latina, especialmente os do Mercosul, não trouxe os resultados esperados. O crescimento das exportaçóes e do comercio entre os países não atingiu os níveis do comercio inter-regional como ocorre entre os países da União Europeia e do bloco asiático e da América do Norte. Segundo cálculo dos autores, baseados nos dados da Organização Mundial do Comércio (OMC), enquanto, em 2015, o comércio entre os países da América do Norte (incluído o México) foi de 49\% do total do comércio mundial daqueles países, o da União Europeia $64 \%$ e da Ásia 53\%, na América Central e do Sul foi de apenas 26\%. O total do comércio entre o Brasil e os demais países da América Latina (incluído o México) foi de 27,3\% e com o Mercosul de apenas 13\%. Além disso, as exportaçóes do Brasil para os demais países da região foram concentradas em bens intermediários, sendo que a expansão industrial das atividades ligadas ao complexo agropecuário dos estados do Rio Grande do Sul, Santa Catarina, São Paulo e da região Centro-Oeste do país foram orientadas para exportaçôes para a Ásia, especialmente para a China.

Além das AIRs, existiam no Brasil, em 2018, um total de 84 microrregiōes geográficas com emprego industrial entre 5 mil e 10 mil, das quais 45 estão localizadas dentro da área do novo do polígono, muitas complementares às AIRs de maior escala, ou dedicadas a atividades típicas de mercados locais. As outras 39 estáo distribuídas de forma dispersa no restante do país.

Mais recentemente, novos trabalhos vêm analisando as tendências de crescimento e desigualdades regionais e sociais no Brasil. Monteiro Neto, Silva e Severian (2019a), incluíram as microrregiōes com mais de 5 mil empregos como AIRs. Por esse critério, os autores identificaram a existência ou criação de várias pequenas aglomeraçóes industriais dispersas no vasto território do país. Ressalte-se que algumas são unidades 
processadoras de insumos de origem mineral, vegetal ou agropecuário (metalurgias, cimento, madeira, frigoríficos, beneficiamento de cereais etc.), voltados para exportação internacional ou inter-regional, porém, a maioria não gera integração produtiva, como demonstra o longo debate sobre os limites da base exportadora no desenvolvimento industrial (Friedman e Alonso, 1969).

Além disso, é fundamental destacar que a escala favorece o dinamismo do setor industrial, por possibilitar maior conexão intrassetorial (Marshall, 1982) ou complementaridade entre setores (Jacobs, 1969). No nosso entendimento, essas regióes são extremamente importantes para o desenvolvimento econômico e para o bem-estar social, porém, de forma isolada, elas não geram efeitos interindustriais dinâmicos e capazes de promover um verdadeiro processo de industrialização. Esses aspectos são importantes para se analisar o desenvolvimento do oeste dos estados de Santa Catarina, Paraná e São Paulo nas últimas décadas, bem como das fronteiras agropecuária e mineral no desenvolvimento das regiôes Centro-Oeste e Norte do país e do oeste do Nordeste (Diniz, 1987).

Há também pequenas unidades industriais voltadas para a produção de bens de consumo generalizado e orientadas para os mercados locais ou regionais (padarias, alimentos, bebidas, confecçôes móveis etc.). Igualmente, essas unidades são importantes do ponto de vista econômico e social, porém não atingem escala e capacidade de criar efeitos interindustriais dinâmicos.

Observe-se que mesmo na chamada região Centro-Sul do Brasil, historicamente identificada como a região mais desenvolvida do Brasil, no diagnóstico elaborado por Celso Furtado e que serviu de base para a criação da Sudene e das respectivas políticas para o Nordeste (GTDN,1967), várias sub-regiốes como o norte e nordeste de Minas Geais e o Espírito Santo não tiveram impacto industrial. O Rio de Janeiro teve sua grande expectativa de expansão industrial frustrada. Da mesma forma, a metade do Rio Grande do Sul tampouco recebeu investimentos industriais. Fica claro, então, a natureza desequilibrada do desenvolvimento regional dentro da própria região mais desenvolvida do Brasil, o Centro-Sul. Isso confirma que o desenvolvimento econômico em geral, e industrial em particular, não se distribui de maneira uniforme no território. 


\section{Efeitos sobre o emprego industrial}

Entre 2000 e 2018, o emprego total de todas as AIRs do país subiu de 3,8 milhóes para 5,6 milhôes, com crescimento de $47 \%$. Dentro do novo polígono, o emprego subiu de 3.071 mil para 4.442 mil, ou seja 45\%. Considerando que a RM de São Paulo reduziu o número de empregos industriais de 662 mil para 505 mil, enquanto no restante das AIRs no polígono ampliado subiu de 2.409 mil para 3.937 mil, ou seja 63\%, estando, portanto, acima da média brasileira.

A desconcentraçáo industrial da RM de São Paulo decorreu de dois movimentos. O primeiro, pela localização das indústrias de tecnologia mais sofisticada em áreas próximas à RM de São Paulo, especialmente no grande eixo Sáo Carlos-Campinas-São Paulo-São José dos Campos (Diniz e Razavi, 1999; Diniz e Campolina, 2007) e o segundo, o crescimento das indústrias vinculadas à base agropecuária e voltadas para exportaçáo, no oeste dos estados e Santa Catarina, Paraná e São Paulo e seu avanço em direção à regiáo Centro-Oeste.

\subsubsection{Participação no VTI e nas exportações}

Como não há disponibilidade de informaçóes do VTI e das exportaçóes por microrregiáo, tomamos os dados da PIA e da Secex, por UF, como indicadores da distribuiçấo da produção industrial e das exportaçóes por estados, informaçôes importantes no quadro da organização federativa do país.

Como se pode observar pela tabela 1, a participação dos estados de Minas Gerais, São Paulo, Paraná, Santa Catarina e Rio Grande do Sul no VTI do Brasil, embora relevante, vem caindo paulatinamente ao longo do século XXI, diminuindo de $76 \%$ em 2000 para 70\% em 2017. Isso ocorre, no entanto, mais pelos efeitos da queda relativa da RM de São Paulo do que do restante da região analisada.

Do ponto de vista macroespacial, o resultado indica o crescimento de outras regiôes do país, o que será objetivo de análise nos próximos itens deste trabalho. Quando se analisam, no entanto, as características da estrutura industrial, observa-se que a indústria tecnologicamente mais sofisticada e com maior capacidade de integração, e diversificação, continua concentrada na RM de São Paulo. 
TABELA 1

Brasil: participação no VTI

(Em \%)

\begin{tabular}{lccc}
\hline UF & 2000 & 2010 & 2017 \\
\hline Norte & 4,22 & 4,94 & 4,95 \\
Amazonas & 3,24 & 3,83 & 3,52 \\
Nordeste & 8,54 & 9,50 & 10,51 \\
Ceará & 1,38 & 1,43 & 1,69 \\
Pernambuco & 1,21 & 1,66 & 2,31 \\
Bahia & 4,03 & 4,44 & 4,17 \\
Sudeste & 65,66 & 60,10 & 55,90 \\
Minas Gerais & 8,85 & 10,10 & 9,83 \\
Espírito Santo & 1,66 & 1,27 & 1,39 \\
Rio de Janeiro & 7,91 & 7,95 & 7,22 \\
São Paulo & 47,24 & 40,78 & 37,46 \\
Sul & 19,39 & 20,70 & 22,47 \\
Paraná & 6,15 & 7,73 & 8,33 \\
Santa Catarina & 4,57 & 5,29 & 6,28 \\
Rio Grande do Sul & 8,67 & 7,68 & 7,86 \\
Centro-Oeste & 2,21 & 4,77 & 6,17 \\
Goiás & 1,07 & 2,34 & 2,91 \\
\hline
\end{tabular}

Fonte: PIA.

Elaboração dos autores.

Obs.: Preços correntes.

Embora o Brasil exporte apenas 13\% de sua produção industrial, a participação dos estados de Minas Gerais, São Paulo, Paraná, Santa Catarina e Rio Grande do Sul foi reduzida de $76 \%$ para $69 \%$ ao longo do século XXI, indicando mudanças especiais nas exportações industriais. Quando se analisa, porém, a estrutura das exportaçóes, observa-se que os bens de maior agregação de valor se originam nesses estados. O peso de estados como Pará, Maranhão, Pernambuco, Espírito Santo e Bahia são de exportação de bens de baixa complexidade, com predominância de matérias-primas semielaboradas ou de produtos de baixa sofisticação tecnológica (alumina, celulose, ferro bruto, madeira etc.).

Apesar disso, em seu conjunto o Brasil é exportador de bens industriais de baixo valor agregado, indicando nossa defasagem em relação à dinâmica da economia mundial, fato de alta preocupação, especialmente à luz do processo de desindustrialização pelo qual vem passando o país. 
TABELA 2

Participação nas exportações de produtos industrializados

(Em \%)

\begin{tabular}{lrcc}
\hline UF & 2000 & 2010 & 2018 \\
\hline Norte & 5,48 & 4,44 & 4,18 \\
Pará & 3,38 & 3,28 & 3,10 \\
Nordeste & 8,03 & 10,57 & 10,63 \\
Maranhão & 1,65 & 0,92 & 2,20 \\
Bahia & 4,05 & 6,66 & 5,65 \\
Sudeste & 63,53 & 63,12 & 61,19 \\
Minas Gerais & 9,59 & 11,36 & 10,11 \\
Espírito Santo & 3,66 & 4,40 \\
Rio de Janeiro & 4,45 & 4,21 & 7,55 \\
São Paulo & 3,58 & 43,88 & 39,13 \\
Sul & 45,91 & 19,47 & 20,01 \\
Centro-Oeste & 22,09 & 2,40 & 3,98 \\
Mato Grosso do Sul & 0,88 & 0,93 & 1,70 \\
Goís & 0,12 & 0,76 & 1,65 \\
Brasil' & 0,35 & $105.415,6$ & $113.480,7$ \\
\hline
\end{tabular}

Fonte: Comex Stat/Ministério da Economia.

Elaboração dos autores.

Nota: ${ }^{1}$ Valor total das exportações em US\$ milhões - FOB.

\subsubsection{0 crescimento industrial nordestino}

O crescimento industrial do Nordeste do Brasil, foco prioritário da política regional desde a década de 1950, foi também significativo no século XXI. Além do crescimento das AIRs já existentes, foram criadas mais onze entre 2000 e 2018.

Os aspectos determinantes desse crescimento foram de duas naturezas: a primeira, pela combinaçáa dos projetos atraídos pelo menor custo do trabalho na regiáo, reforçados pelo aumento da demanda de bens de consumo corrente, especialmente pelos efeitos das políticas sociais horizontais. Esses projetos se beneficiaram também do sistema de incentivos fiscais introduzidos desde o início da década de 1960, com a criação da Sudene.

Inicialmente foram transferidas unidades industriais antes localizadas nos estados do Sul e Sudeste ou criadas novas unidades pelas empresas dessas regióes nos estados nordestinos, especialmente nos setores têxtil, confecçốes e calçados, 
alimentos etc., sendo parte da produção voltada para o mercado nacional. Em seguida houve expansão ou instalação de novas atividades pelos empresários locais, especialmente pela expansão da demanda regional decorrente das políticas horizontais de distribuição de renda e benefícios sociais.

A segunda, pelos grandes projetos induzidos pelos incentivos fiscais combinados com decisôes políticas que levaram à instalação de grandes projetos estruturantes na regiáo, como as fabricas da Ford, em Salvador (Bahia) e da Fiat em Goiana (Pernambuco), a refinaria da Abreu e Lima (Pernambuco), a petroquímica e o estaleiro Atlântico Sul, em Suape (Pernambuco), a siderurgia no Pecém (Ceará), além de outros de menor escala.

Graças a essas políticas, o Nordeste ampliou seu emprego industrial total de 578 mil em 2000 para 903 mil em 2018, com crescimento de 56\%, maior que a média brasileira, que foi de 40\%. No conjunto, as AIRs ampliaram seu emprego de $366 \mathrm{mil}$ para 632 mil, ou seja, 72\%, contra 47\% para a média brasileira. Com relação ao VTI, a participação dos nove estados que compóem a regiáo Nordeste subiu de 8,5\% para $10,5 \%$ do total nacional. Elevou também a sua participação nas exportaçóes de bens industrializados de $8 \%$ para $10,6 \%$ no total nacional no mesmo período, embora em produtos de menor valor agregado.

A conclusão é que, embora ainda aquém das necessidades de uma melhor distribuição das atividades econômicas no território brasileiro, especialmente em relação à região mais pobre e de ocupação antiga, o crescimento industrial vem sendo importante para o desenvolvimento do Nordeste.

Há, no entanto, grande preocupação sobre a viabilidade e maturação desses projetos, pelos efeitos da crise econômica e das mudanças na orientaçáo política do governo federal. Os casos mais graves são os dos projetos vinculados à Petrobras, em Pernambuco, a saber: o Estaleiro Atlântico Sul, a Refinaria Abreu e Lima e o polo petroquímico.

Observe-se que os resultados antes apontados decorreram mais de políticas sociais horizontais e de decisóes políticas ad hoc do que da política regional propriamente dita. Nesse sentido, a política regional para o Nordeste e para outras regiôes estagnadas ou de baixo dinamismo no Brasil deveria combinar duas dimensôes fundamentais: i) manutenção e ampliação das políticas horizontais de distribuição de renda; e 
ii) a reorientação das políticas de incentivos para projetos com capacidade de induzir efeitos estruturantes, com capacidade de integração e diversificação. Supostamente, o conjunto de grandes projetos em atividades diversificadas decididos para a regiáo teriam capacidade motriz, para usar a expressáo de Perroux (1969), e, portanto, com potencial para induzir uma relativa integração e diversificação industrial.

\subsubsection{Enclaves exportadores e pequenas aglomerações industriais dispersas}

Nas regiōes de ocupação recente e com fronteira agropecuária dinâmica, de exploração de recursos florestais ou minerais, algumas microrregiôes têm recebido unidades industriais de pequeno e médio porte. Consideradas as extensas dimensōes geográficas de muitas dessas microrregióes, as atividades, no entanto, às vezes estão dispersas em municípios distantes, não criando integração produtiva. Enquadra-se nesse caso estados como Rondônia, com quatro unidades; Pará, com três; Mato Grosso, com duas; Mato Grosso do Sul, com duas; e Goiás, com cinco. Essas atividades têm duas características distintas. Em alguns casos, estão espalhadas e em atividades agroindustriais (frigoríficos, beneficiamento de cereais), exploração florestal (madeireiras). São, em geral, enclaves exportadores para o exterior ou para outras regióes do país, sem capacidade de criarem expansão industrial diversificada e em maior escala, como ilustra o célebre debate sobre o papel da base exportadora no desenvolvimento industrial (Friedman e Alonso, 1969). No entanto, elas são importantes para as respectivas regióes, pelo seu impacto econômico e social, e mesmo para um melhor aproveitamento dos recursos, pela geração de renda, embora como menor impacto sobre a ocupação.

Existe ainda grande número de microrregióes, em estados com ocupação populacional dispersa e baixo nível de desenvolvimento, com ocupação industrial entre 5 mil e 10 mil pessoas em atividades voltadas para atender aos mercados locais, a exemplo de alimentos, bebidas, confecçôes, móveis, material de construção, oficinas de reparação e manutenção etc. Têm, em geral, pequena integração com as estruturas industriais de outras regiốes. Essas pequenas aglomeraçóes industriais dispersas estão, predominantemente, no leste, nordeste e norte de Minas Gerais, o vasto interior do nordeste e a metade sul do Rio Grande do Sul.

Nesse sentido, enquanto nos estados mais industrializados as AIRs participam com mais de $95 \%$ do emprego total, naqueles menos industrializados e integrados industrialmente essa participação cai para uma média de 30\%. 
A expansão da fronteira agrícola atraiu a localização de atividades industriais, como produtoras de insumos, processadoras de bens primários ou mesmo voltadas para o consumo regional. Esse movimento trouxe consigo a construçáo de novas centralidades, com dinamismo propício à atração de indústrias com maior integração produtiva. Assim, uma política regional deve considerar a importância dessas novas atividades, o que se mostra fundamental no enfrentamento das desigualdades regionais do país (Kaldor, 1966).

\subsubsection{Integração das AIRs próximas: adensamentos ou corredores industriais}

Levando-se em conta a relevância da escala das 149 AIRs existentes em 2018, 47 possuíam mais de 30 mil empregos cada, das quais 41 estavam dentro do chamado polígono estendido (mapa 2). Considerada a estrutura produtiva e a proximidade geográfica entre muitas dessas áreas, adensamentos, corredores ou outras formas de integração regional foram se formando, de modo que atualmente chegam a participar com elevada parcela da produçáo industrial do país, confirmando uma característica mundial de que a indústria não se distribui de maneira uniforme no território - porém também não com o nível de desigualdade macroespacial existente no Brasil. Essa é a razão pela qual deve o Estado, por meio de suas políticas, atuar para reduzir as desigualdades, como comprovam as diferentes políticas mundiais contemporâneas de desenvolvimento regional, com destaque para o conjunto de estudos sobre coesão territorial na União Europeia (Regional Studies, v. 54, 2020) e as políticas de desconcentração territorial da China (Dunford e Liu, 2015).

Destaca-se o grande adensamento que vem sendo feito no estado de São Paulo, combinando a desconcentração de sua área metropolitana e a formação de um grande colar próximo a ela, a chamada área metropolitana estendida (Diniz e Diniz, 2004) ou Macrometrópole Paulista (Proença e Santos Junior, 2019). A esse adensamento deve-se acrescentar a extensão no sentido do noroeste paulista, acompanhando os eixos rodoviários Bandeirantes e Anhanguera e suas ligaçóes transversais, na grande faixa entre as cidades de São Paulo e Ribeirão Preto, incluídas Jundiaí, Campinas, Americana, Limeira, Piracicaba, Rio Claro, Araraquara, Sáo Carlos, além de outras de menor escala. Para o oeste paulista, acompanhando a rodovia Castelo Branco, no sentido de Sorocaba e daí para Botucatu e Bauru. No sentido nordeste, de São José dos Campos para Taubaté e daí para o Vale do Paraíba fluminense, onde estáo sendo instaladas unidades automotivas (Resende e Porto Real). Por fim, a ligação entre o ABC 
Paulista e a regiáo industrial de Cubatão e o porto de Santos, pela rodovia Anchieta, com extensão de apenas $60 \mathrm{~km}$, mas com a mancha industrial segmentada pela serra do mar. Na faixa nordeste-oeste do estado, a integração está sendo fortalecida pelo vetor perimetral Sorocaba-Campinas-São José dos Campos-Porto de São Sebastião.

Embora esteja perdendo competitividade, a participação relativa de São Paulo na produção industrial do país ocorre em sua área metropolitana e não no restante do estado. No conjunto, o estado ainda detém $40 \%$ da participação nacional.

No estado do Paraná, além da dimensão industrial no entorno de Curitiba, forma-se um eixo industrial entre Londrina e Maringá, passando por Arapongas e Apucarana, com mais de 100 mil empregos industriais. Em Santa Catarina, há a grande faixa litorânea entre Joinville e Florianópolis, interligadas pela BR-101, incluídas as áreas industriais de Jaraguá do Sul, Itajaí, Blumenau, com mais de 300 mil empregos industriais. No Rio Grande do Sul, tem o eixo Porto Alegre-Caxias do Sul, pela BR-116, com bifurcaçóes para Gramado, Canela e outras áreas próximas, com mais de 350 mil empregos industriais.

Ainda dentro do polígono estendido, as áreas industriais de Goiânia e Anápolis têm potencial de se integrarem, pela sua proximidade e diversidade. Goiânia e Anápolis possuem dinâmica e potencial destacados, com estrutura diversificada em Goiânia e polo farmacêutico em Anápolis, cidade que possui ainda potencial relacionado com o Porto Seco, com o aeroporto de carga e a base militar. Discute-se a viabilidade de implantaçáo da montagem do Gripen naquela cidade, o que depende de decisôes políticas. Há que se considerar, no entanto, que a expansão industrial no estado de Goiás gozou de incentivos federais por meio da Sudeco, bem como de incentivos e outras facilidades proporcionados pelo governo do Estado. 
MAPA 2

Brasil: distribuição espacial das AIRs com mais de 30 mil empregos industriais (2018)

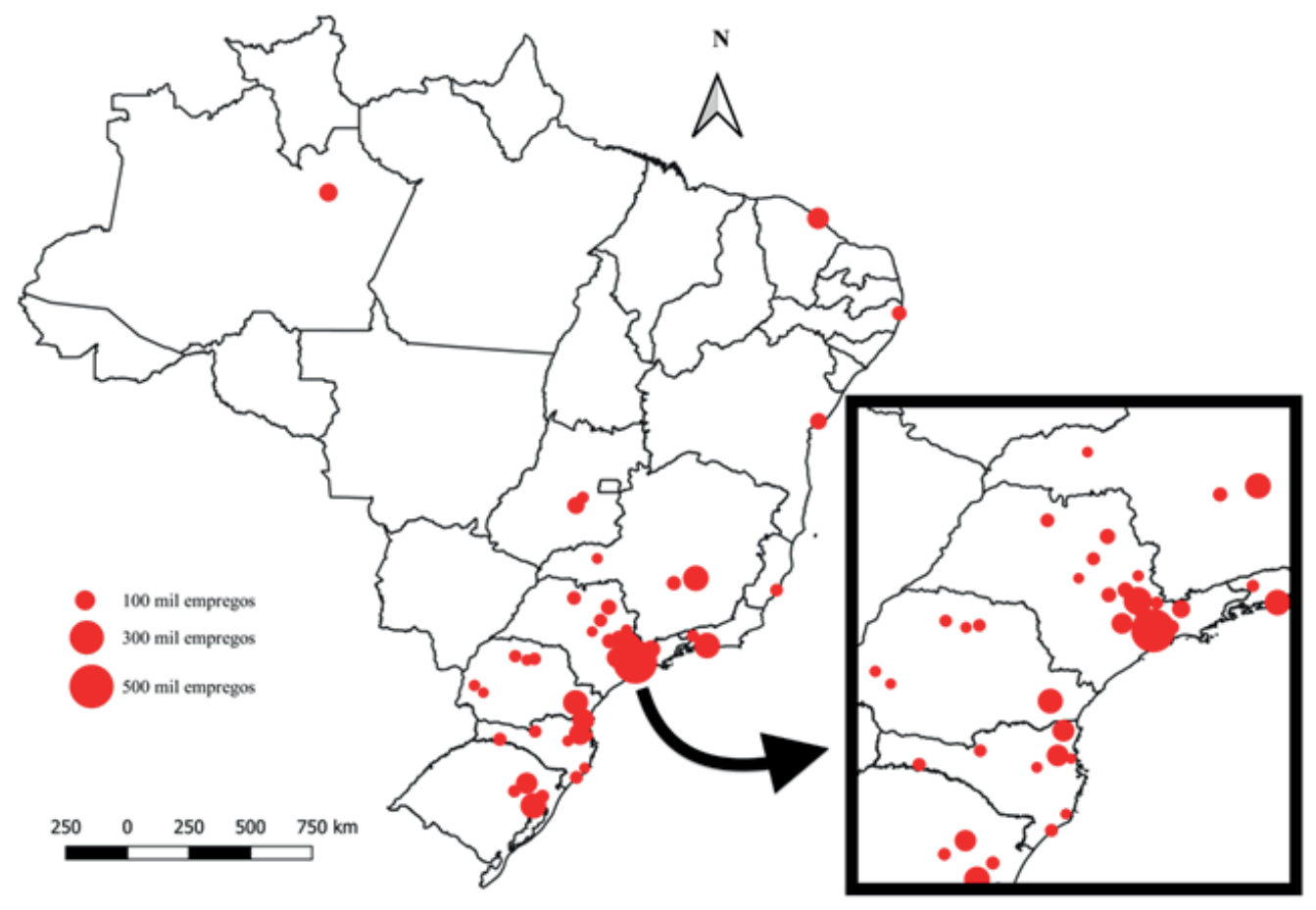

Fonte: Rais.

Elaboração dos autores.

Em Minas Gerais, além do aglomerado da RM de Belo Horizonte, das microrregiôes de Divinópolis e Uberlândia, está se formando um pequeno eixo entre Pouso Alegre e Itajubá, passando por Santa Rita do Sapucaí. Apesar de nenhuma microrregião apresentar individualmente mais de 30 mil empregos industriais, esse adensamento se destaca pela relevância de sua integração e pela complexidade setorial.

As outras seis AIRs com mais de 30 mil empregos industriais cada têm distribuição dispersa (Manaus, Fortaleza, Recife, Salvador, Vitória e Rio de Janeiro).

Entre essas seis, três têm potencial para ampliarem suas integraçóes. No Ceará, a ligação entre as AIRs de Pacajus e o Porto do Pecém, passando por Fortaleza. O distrito de Pecém foi transformado em Zona Econômica Especial, gozando, portanto, de incentivos extras, o que tem atraído projetos industriais para a região. Em Pernambuco, o eixo Goiana 
(Fiat) a Suape (estaleiro e petroquímica), passando por Recife. ${ }^{4} \mathrm{~A}$ aglomeração industrial de Salvador possui escala, inclusive com a presença do polo petroquímico e da montadora Ford, além de uma relativa proximidade com Feira de Santana, que é um polo industrial bastante diversificado. No entanto, a recente decisão da Ford em encerrar suas atividades no Brasil poderá ter impacto negativo para a região de Salvador.

A conclusão é de que as grandes aglomeraçóes industriais que se expandiram no Nordeste do país só foram viabilizadas através das políticas regionais e do sistema de incentivos fiscais. A continuidade deste movimento, que seria benéfico à melhor distribuição da atividade produtiva no território nacional, especialmente para a regiâo mais pobre depende da manutençáo e aprimoramento do sistema de incentivos fiscais e de sua readequação em prol da eleição de prioridades com capacidade de integração e diversificação.

As outras três grandes aglomeraçóes encontram-se relativamente isoladas. Manaus foi criada por meio de um efetivo e amplo sistema de incentivos fiscais proporcionados à Zona Franca de Manaus. A regiáo, além de geograficamente isolada, não criou capacidade endógena de pesquisa e progresso técnico, sendo dependente da importaçáo de componentes, Do projeto original, de uma zona de processamento de exportaçôes (ZPE), se transformou em uma zona de processamento de importaçôes (ZPI), como destacado por Diniz e Santos (1999). A aglomeração industrial de Vitória funciona como localização isolada, viabilizada pelo Porto de Tubarão, mas com pouca integração produtiva e inter-regional. A aglomeraçáo do Rio de Janeiro está estagnada e em decadência há anos, como indicam a redução do seu peso relativo tanto no emprego como no VTI.

TABELA 3

Adensamento de AIRs

\begin{tabular}{llrrr}
\hline UF & Microrregiões & 2000 & \multicolumn{1}{c}{2010} & 2018 \\
\hline Ceará & Fortaleza, Pacajus e Baixo Curu & 99.210 & 166.108 & 155.929 \\
Pernambuco & Goiana, Itamaracá, Recife e Suape & 85.312 & 126.471 & 130.298 \\
Minas Gerais & Pouso Alegre, Santa Rita do Sapucaí e Itajubá & 26.311 & 51.193 & 51.282 \\
São Paulo & Adensamento de 16 microrregiões (300km de extensão) & 1.388 .637 & 1.869 .402 & 1.643 .229 \\
Paraná & Maringá, Apucarana e Londrina & 72.455 & 124.829 & 114.547 \\
Santa Catarina & Joinville, Blumenau, Itajaí, Tijucas e Florianópolis & 190.224 & 328.957 & 322.157 \\
Rio Grande do Sul & Caxias do Sul, Montenegro, Gramado-Canela e Porto Alegre & 342.012 & 451.728 & 395.584 \\
\hline
\end{tabular}

Fonte: Rais.

4. A expansão industrial do estado de Pernambuco, que trouxe incentivos fiscais para o Nordeste, foi mobilizada por meio de decisões políticas do governo federal. Essa expansão, no entanto, está sujeita aos riscos das mudanças de orientação política e econômica do governo federal, o que poderá comprometer os importantes projetos estruturantes implantados, a maioria vinculados à Petrobras. 
A análise aqui desenvolvida demonstra que o núcleo de maior dimensão e integraçáo industrial continua localizado na chamada área do polígono industrial e de seu alargamento. As demais AIRs de maior magnitude foram viabilizadas pelo sistema de incentivos fiscais e por decisóes políticas, especialmente no Nordeste do país, embora o menor custo relativo, especialmente do trabalho, e as políticas sociais de distribuição de renda também tenham contribuído.

\section{SÍNTESE DO DESENVOLVIMENTO REGIONAL RECENTE}

Após várias décadas de política regional explícita, com altos e baixos e resultados não desprezíveis, a partir do início do século XXI a questão regional ganhou novos contornos por causa dos efeitos indiretos das políticas de renda e pela combinaçáo do sistema de incentivos fiscais com decisôes políticas na alocação de novas plantas industriais, especialmente para o litoral fluminense e para o Nordeste. A nosso ver, do ponto de vista regional, o crescimento industrial pode ser sinteticamente caracterizado da forma como exposto a seguir.

- A consolidação e expansão do polígono industrial antes caraterizado por Diniz (1993) e seu alargamento: no oeste dos estados de Santa Catarina, Paraná, São Paulo, Minas Geais, sudeste de Mato Grosso do Sul e sudoeste de Goiás, acompanhando o crescimento agropecuário dessas regiốes. A esse alargamento deve-se acrescentar o eixo Cataláo-Goiânia-Anápolis e o sul fluminense, com crescimento industrial e diversificação produtiva. Formou-se um novo polígono industrial cujos vértices podem ser aproximadamente tomados como Belo Horizonte, Anápolis, Rio Verde, Campo Grande, Foz do Iguaçu, Santa Cruz do Sul, Porto Alegre, Florianópolis, Resende, Belo Horizonte. Nele estão incluídas a totalidade dos estados de São Paulo, Paraná, Santa Catarina, Mato Grosso do Sul e Goiás, parte das AIRs de Minas Gerais e Rio Grande do Sul e uma AIR no sul do Rio de Janeiro. Nessa área estão as atividades tecnologicamente mais avançadas, com maior integração produtiva e aproximadamente três quartos do valor da transformação industrial e do emprego da indústria de transformação do país.

- A expansáo industrial na regiáo Nordeste do país, onde, além do crescimento das AIRs já existentes, foram criadas onze novas, com diversificação e potencial de integração produtiva. Associado às políticas de incentivos anteriormente estabelecidas, os menores custos também atraíram indústrias que antes estavam instaladas nos estados do Sudeste e Sul, com transferência ou criação de novas plantas, as quais 
foram transferidas para o Nordeste, ou implantadas novas plantas nessa região. Em segundo lugar, a expansão das políticas horizontais de transferência de renda (o aumento do salário mínimo real, o programa Bolsa Família, o Benefício de Prestação Continuada, a merenda escolar), que ampliaram o poder de compra dos grupos de menor renda, com grande efeito de demanda e estímulo aos investimentos produtivos, o que beneficiou as regióes menos desenvolvidas. Em terceiro lugar os efeitos dos grandes investimentos em infraestrutura física e social (estradas, ferrovias, portos, aeroportos, usinas hidroelétricas, solar e eólica, o programa Mais Médicos, criação de novas universidades e novos campi da rede de universidades e institutos tecnológicos federais, entre outros) também beneficiaram a região. Em quarto lugar, o pacote de projetos industriais implementados por decisóes políticas do governo federal, como montadoras automotivas, estaleiros, refinarias e petroquímicas. Destacam-se as unidades automotivas de Salvador e de Goiana (Pernambuco), o estaleiro naval Atlântico Sul em Ipojuca (Pernambuco), a Refinaria Abreu e Lima e Petroquímica próximas a Suape (Pernambuco), a Companhia Siderúrgica do Pecém (Ceará). Essas ações vêm criando impactos diferenciados sobre o território. Elas exigem, no entanto, maior prazo de maturação e correm riscos pelas mudanças de orientação política do governo federal.

- Estaleiros navais no litoral fluminense, o Complexo Petroquímico Comperj e o Complexo Portuário-Industrial do Açu. Todos esses projetos teriam grande impacto sobre o crescimento industrial do estado do Rio de Janeiro, o qual vem em um processo histórico de perda de dinamismo e participação. Ressalte-se que a periferia da cidade do Rio de Janeiro, a denominada Baixada Fluminense, e o restante do estado encontram-se estagnados.

- Atividades industriais dispersas no território nacional, com duas características distintas: enclaves exportadores em atividades agroindustriais (frigoríficos, beneficiamento de cereais, insumos) em pontos nodais da grande fronteira agropecuária distante, especialmente Mato Grosso, Rondônia e Pará; e atividades industriais dispersas, produtoras de bens de consumo generalizado (alimentos, bebidas, confecçóes), insumos de demanda local, como cerâmicas e outros materiais de construção, oficinas e artesanatos mecânicos etc., em regiōes de ocupação dispersa e baixo nível de desenvolvimento, como são o norte e nordeste de Minas Geais, o estado do Espírito Santo, a metade sul do Rio Grande do Sul e o interior do nordeste, especialmente no estado da Bahia.

Em visão mais abrangente, mas compatível com a análise aqui desenvolvida, Brandão (2019a) caracteriza o desenvolvimento regional brasileiro em cinco tipologias de territórios, segundo a natureza dos investimentos: i) estimulados pela demanda de commodities; ii) orientados pela infraestrutura; iii) atraídos pela força 
inercial da concentração; iv) investimentos industriais isolados como enclaves; e v) investimentos induzidos pelas políticas sociais.

Em síntese, embora tenham surgido e se expandido várias AIRs em outas partes do país, o núcleo mais consolidado da indústria brasileira continua concentrado na chamada região Centro-Sul do país, confirmando a intepretação anterior de que a perda de participação da RM de São Paulo não conduziu a uma mudança macroespacial mas sim a um fortalecimento da macrorregião que vai do centro de Minas Gerais ao nordeste do Rio Grande do Sul e de seu alargamento para Mato Grosso do Sul, Goiás e sul do estado do Rio de Janeiro.

Houve, no entanto, vários grandes projetos industriais localizados no litoral do estado do Rio de Janeiro e no Nordeste do país, com capacidade estruturante, que poderiam alterar o desenvolvimento regional da indústria brasileira. Esses empreendimentos exigem, no entanto, a manutenção dos incentivos e das decisóes governamentais e orientação das políticas macroeconômicas do governo federal.

\section{DESAFIOS PARA AS POLÍTICAS REGIONAIS E INDUSTRIAIS NO BRASIL}

\subsection{Compatibilização entre Estado, governo, mercado, sociedade}

Em primeiro lugar, é preciso ter consciência de que não é possível um sistema de planejamento e atuação compreensiva, que abarque todas as dimensóes dos sistemas econômicos, políticos e sociais. Essa tentativa fracassou em todos as experiências que a implementaram. Estamos em uma economia mercantil e de mercado, em que os agentes privados (empresas, pessoas, organizaçóes civis) têm certa autonomia de decisóes e entendimentos e vontades diferenciadas. O governo também tem contradiçôes, seja pelas diversas visões políticas dos diferentes grupos políticos que assumem a gestão em cada mandato, seja pelas próprias contradiçóes entre os governos das várias instâncias federativas, e seus respectivos partidos e agrupamentos políticos, seja pela capacidade de influência dos diferentes agentes privados (empresas, pessoas, organizaçóes etc.). Daí o papel central do Estado - Estado como arranjo jurídico-institucional, baseado em normas e princípios estáveis e rigidamente regulado por sua constitucionalidade e as respectivas leis e normas. 
Portanto, o Estado deve estar, acima dos interesses privados e das peculiaridades governamentais para que tenha capacidade de mediar os conflitos entre mercado, governo e sociedade civil, de forma a se estabelecer objetivos, princípios e normas para o funcionamento da sociedade. Já o mercado precisa ser monitorado e regulado pelo governo, náo podendo funcionar dentro de um ambiente liberal, o qual só cria desigualdades. Ao Estado cabe, então, o papel central de mediar os interesses do mercado, da sociedade e do próprio governo, para que as açóes públicas, privadas ou individuais possam compatibilizar os interesses econômicos, guiados pelo mercado, com os interesses sociais e políticos básicos. Desse modo, é o Estado o legítimo representante e coordenador das diretrizes e prioridades para o atendimento das necessidades fundamentais da sociedade.

O Estado não é um ente abstrato. Sua estrutura e forma de ação resultam da configuração histórica e dos valores culturais que o fundamentam e das forças e conflitos de interesses dos diferentes agentes que o compóem. Nesse sentido, é fundamental que tenha poder, capacidade e legitimidade para arbitrar conflitos e definir prioridades, o que só é possível mediante um legítimo sistema democrático.

Para que o Estado cumpra seu papel é preciso o sustento de um competente, eficiente e dinâmico sistema de planejamento. Como os sistemas econômico, político e social funcionam dentro de um ambiente de expectativas e incertezas, não é possível uma previsão clara do futuro e dos desafios e mudanças que podem surgir, situaçóes muitas vezes não conhecidas, imprevistas ou acidentais. Por isso, é essencial que os objetivos, as expectativas e as formas de atuação do Estado estejam sempre bem ajustadas. As metas devem ser permanentemente reavaliadas e adaptadas conforme a necessidade, daí também a importância do caráter dinâmico da atuação pública e privada.

Consideradas as desigualdades regionais no desenvolvimento brasileiro e o papel do crescimento industrial na redução dessas desigualdades, torna-se central a rediscussão do papel das políticas regionais. Essas devem ser, no entanto, reformuladas e adequadas à luz das mudanças estruturais em curso, com definição clara de objetivos e prioridades da política regional e de seu ajustamento temporário. 


\subsection{Desindustrialização e desafios tecnológicos}

O primeiro grande desafio está relacionado com a urgente necessidade de se retomar uma efetiva política de reindustrialização do país, após o forte retrocesso ocorrido desde a década de 1980 e acelerado nas últimas décadas. Nesse período, a participação da indústria manufatureira no PIB caiu de $23 \%$ para menos de $10 \% .{ }^{5}$ A partir de 2014 , o agravamento da crise econômica brasileira aprofundou a crise do setor industrial. No atual contexto, ela está sendo drasticamente afetada pela pandemia, cujos resultados são desconhecidos e de difícil previsão.

Apesar de tudo isso, embora perca peso relativo na geração da renda e da ocupação, a indústria manufatureira continua sendo coração e cérebro da economia, pois dependem dela os elementos centrais na competiçáo e no ganho de eficiência, inclusive para a maioria das demais atividades econômicas, políticas e sociais. Por sua vez, as mudanças estruturais da economia ampliam a integração do conjunto das atividades produtoras de bens (agropecuária, extrativa mineral, manufatura), com os servidos, parte dos quais imbricados na própria produção de bens. Especialmente com as mudanças tecnológicas e organizacionais dos processos produtivos e comerciais, com a generalizada influência das tecnologias da informação e comunicação e suas articulaçôes com a engenharia de precisão e seus desdobramentos em termos de automação e robotização generalizadas, sem avaliar as consequências da inteligência artificial.

Nesse sentido, o arcabouço teórico, empírico e analítico para se analisar a dinâmica econômica, suas articulaçóes e implicaçóes encontra-se diante de um grande desafio para as diferentes dimensóes da vida econômica, política e social.

Por sua vez, o desenvolvimento industrial está cada vez mais articulado e dependente do desenvolvimento científico e tecnológico. No caso do Brasil, essa situação se agrava diante da grande corrida científica e tecnológica mundial e da pequena ênfase das políticas públicas e do empenho empresarial para enfrentar esse desafio. Isto porque

5. A título de comparação, em 2018, a indústria manufatureira da Coreia do Sul e a da China participavam com $29 \%$ dos respectivos PIBs; a Alemanha, com 23\%; o Japão, com 20\%. A participação brasileira nas exportações mundiais caiu de $0,8 \%$ para $0,6 \%$; a demanda interna cresceu $60 \%$ e a produção, apenas $34 \%$. Como consequência, as importações de manufaturados subiram de $14 \%$ para $27 \%$ da demanda, com destaque para os bens tecnologicamente mais sofisticados, incluídos insumos industriais (Cano, 2014; Morceiro, 2018; Sarti e Hiratuka, 2017). Destaca-se o aniquilamento da indústria de bens de produção, central para qualquer processo de industrialização com um mínimo de autonomia. 
a política industrial está fortemente vinculada à base científica e tecnológica como suporte e instrumento para o ganho de eficiência e a capacidade de competição.

\subsection{Temas para uma política industrial regionalizada}

Além dos temas centrais antes indicados, a montagem de uma política industrial regionalizada e com visão de médio e longo prazo exige um conjunto de açóes, entre as quais, cabe destacar as que se seguem.

- Reajuste do sistema tributário, com eliminação da guerra fiscal.

- Nova regionalização do país para efeitos de planejamento e políticas regionais, com escalas operacionais diferenciadas, segundo as características territoriais, sua história ocupacional, características naturais, estrutura produtiva, suporte de infraestrutura e articulaçáo urbana como centralidade. Para as regióes densamente ocupadas e industrializadas, como o macropolo paulista e as grandes áreas metropolitanas, talvez se exija uma escala intermediária, possivelmente sendo a mais adequada a das mesorregióes. Para os grandes espaços brasileiros, com ocupação rarefeita, a exemplo da regiáo amazônica e do Centro-Oeste, talvez a regionalização tenha que descer à escala municipal ou da própria cidade. Para as áreas de ocupação e densidade intermediária a regionalização mais adequada talvez seja a das microrregiōes geográficas.

- Sistema de financiamento com prioridades explícitas.

- Orientação da política de ciência e tecnologia que articule o sistema produtivo e empresarial (público e privado) com as instituiçóes de pesquisa e com as instituiçóes de fomento.

- Urgente e enfática retomada dos projetos, antes prioritários, que se encontram paralisados, em especial os estaleiros e as petroquímicas no litoral do Rio de Janeiro e no Nordeste.

- Estabelecimento de critérios de prioridade para empreendimentos com capacidade de integração e diversificação industrial.

- Compatibilização das políticas de desenvolvimento regional com as políticas de infraestrutura, especialmente do sistema de transporte com compatibilidade multimodal (rodoviário, ferroviário, dutoviário), cuja malha é rígida no espaço, com altos custos de investimento e manutenção. Compatibilização desse sistema com a infraestrutura portuária e aeroportuária. 
- Compatibilizar as políticas regionais e de infraestrutura com a visão de um país policêntrico, com vistas a atenuar a megaconcentração metropolitana e distribuir melhor a população no território, preservadas as áreas de proteção, especialmente a Amazônia não antropizada.

- Seleção de centralidades urbanas que facilitem a integração com os demais países da América do Sul como condicionante para a integração econômica, política e social da região.

- Por fim, é fundamental a articulação dessas políticas com a política macro e os objetivos e diretrizes gerais para o desenvolvimento do país e para a constituição de um projeto de nação.

Nesse sentido, há na literatura várias contribuições com o objetivo de encontrar uma melhor reformulação e adequação da política regional brasileira. Pode-se destacar: i) Monteiro Neto (2014), coletânea em que se discutem diversos aspectos do federalismo brasileiro no que se refere à atuação dos diferentes entes federativos (União, estados e municípios) e seus efeitos sobre o desenvolvimento regional (autonomia fiscal, dívidas estaduais, guerra fiscal, parâmetros da Constituição de 1988, natureza multiescalar de atuação e desenvolvimento); ii) o capítulo Desenvolvimento territorial e crescimento inclusivo: avaliaçâo de políticas e propostas de aperfeiçoamento (Ipea, 2018, p. 45-56); iii) Negreiros e Monteiro Neto (2019), com o diagnóstico e a agenda de trabalho sobre a questão regional; e iv) Brandão (2019b), com a análise dos elos faltantes das análises regionais e com uma proposta de agenda para o tema.

Observa-se que esses trabalhos vêm sendo elaborados na esfera das instituições públicas de planejamento, preocupadas com o melhor entendimento das tendências regionais da economia brasileira e com a reformulação das referidas políticas regionais, mas também sustentados na comunidade acadêmica que trabalha sobre o tema.

Existe, portanto, preparação analítica, aparato institucional de análise, equipes qualificadas e diagnósticos elaborados. Falta, no entanto, o encaminhamento político pelas instâncias superiores do Executivo federal à submissão das instâncias parlamentares, para discussão, adequação e aprovação. A partir daí, a montagem do sistema operacional, de monitoramento e acompanhamento.

Essas são as razões fundamentais que justificaram a proposta de reorientação da política de desenvolvimento territorial do país, com a urgente necessidade de política 
que induza uma melhor distribuição da rede urbana e de negócios, na busca, ainda que tardia, da construção de um país policêntrico (Brasil, 2008).

\section{REFERÊNCIAS}

ANDRADE, T. A.; SERRA, R. V. Distribuição espacial da indústria: possibilidades atuais para sua investigação. Estudos Econômicos, v. 30, n. 2, abr./jun. 2000.

AZZONI, C. R. Indústria e reversão da polarização no Brasil. São Paulo: IPE, 1986.

BLUESTONE, B.; HARRISON, B. The desindustrialization of America: plant closing, community abandonment and dismantling of basic industry. New York: Basic Books, 1982.

BRANDÃO, C. A. As ausências e elos faltantes das análises regionais no Brasil e a proposiçáo de uma agenda de pesquisas de longo prazo. Rio de Janeiro: Ipea, 2019a. (Texto para Discussão, n. 2461).

Mudanças produtivas e econômicas e reconfiguração territorial no Brasil no início do Século XXI. Revista Brasileira de Estudos Urbanos e Regionais, v. 21, n. 2, p. 259-279, maio-ago. 2019b.

BRASIL. Estudo da Dimensão Territorial para o Panejamento. Regiōes de Referência Volume III. Brasília: MP; CGEE: 2008.

CANO, W. Raízes da concentração industrial em São Paulo. São Paulo: Difel, 1976.

. (Des)industrialização e (Sub)desenvolvimento. Cadernos de Desenvolvimento, v. 9, n. 15, jul.-dez. 2014.

CASTRO, A. B. de. 7 ensaios sobre a economia brasileira. Rio de Janeiro: Forense, 1971. v. 2.

DEAN, W. A industrialização de São Paulo (1880-1945). São Paulo: Difel, 1971.

DINIZ, C. C. Estado e capital estrangeiro da industrialização mineira. 1978. Dissertação (Mestrado) - Universidade Estadual de Campinas, Campinas, 1978.

Estado e capital estrangeiro da industrialização mineira. Belo Horizonte: Editora UFMG, 1981.

Capitalismo, recursos naturais e espaço: análise do papel dos recursos naturais e dos transportes para a dinâmica geográfica da produção agropecuária e mineral no Brasil e seus efeitos no padrão regional brasileiro. 1987. Tese (Doutorado) - Instituto de Economia, Universidade Estadual de Campinas, 1987.

- Desenvolvimento poligonal no Brasil: nem desconcentração nem continua polarização, Nova Economia, v.3, n 1, 1993. 
DINIZ, C. C.; CAMPOLINA, B. A região metropolitana de São Paulo: reestruturação, re-espacialização e novas funçóes. Santiago: Eure, 2007.

DINIZ, C. C.; CROCCO, M. A. Reestruturação econômica e impacto regional: o novo mapa da indústria brasileira. Nova Economia, v. 6, n. 1, 1996.

DINIZ, C. C.; LEMOS, M. B. Mudança no padráo regional brasileiro: determinantes e implicações. Curitiba: Ipardes, 1986. (Análise Conjuntural).

DINIZ, C. C.; RAZAVI, M. São José dos Campos and Campinas: state-anchored dynamos. In: MARKUSEN, A. R.; LEE, Y.-S.; DIGIOVANNA, S. (Ed.). Second tier cities: rapid growth beyond the metropolis. London: University of Minnesota Press, 1999. p. 97-126.

DINIZ, C. C.; SANTOS, F. Manaus: vulnerability in a satellite platform. In: MARKUSEN, A. R.; LEE, Y.-S.; DIGIOVANNA, S. (Ed.). Second tier cities: rapid growth beyond the metropolis. London: University of Minnesota Press, 1999.

DINIZ, C. C.; VIEIRA, D. J. Brazil: accelerated metropolization and urban crisis. Area Development and Policy, v. 1, n. 2, p. 155-177, 2016.

DUNFORD, M.; LIU, W. (Ed.). The geographical transformation of China. London: Routledge, 2015.

FRIEDMAN, J.; ALONSO, W. (Orgs.). Regional development and planning. Cambridge: MIT, 1969.

GTDN - GRUPO DE TRABALHO PARA O DESENVOLVIMENTO DO NORDESTE. Uma política para o dsenvolvimento econômico do Nordeste. Recife: Sudene, 1967.

IPEA - INSTITUTO DE PESQUISA ECONÔMICA APLICADA. Desafios da naçáo. Brasília: Ipea, 2018. v. 2.

JACOBS, J. The economy of cities. New York: Random House, 1969.

KALDOR, N. Causes of the slow rate of economic growth of the United Kingdom: an inaugural lecture. Cambridge, United Kingdom: Cambridge University Press, 1966.

KALECKI, M. Teoria de la dinâmica econômica. Ciudad de México: Fondo de Cultura, 1973.

LEOPOLDI, M. A. P. Política e interesses na industrialização brasileira. Rio de Janeiro: Paz e Terra, 2000.

LESSA, C. O Rio de todos os Brasis: uma reflexão em busca de autoestima. Rio de Janeiro: Record, 2000.

MARSHALL, A. Princípios de economia. São Paulo: Abril, 1982. 
MASSEY, D.; MEEGAN, R. The anatomy of job loss: the how why and where of employment decline. London: Methen, 1982.

MENDES, P. S.; HERMETO, A. M.; BRITTO, G. Reorganização espacial da indústria de transformação brasileira pós-2008: a evolução do emprego formal no território. Revista Brasileira de Estudos Regionais e Urbanos, v. 13, n. 1, p. 23-44, 2019.

MONTEIRO NETO, A. (Org.). Governos estaduais no federalismo brasileiro. Brasília: Ipea, 2014.

MONTEIRO NETO, A.; SILVA, R. de O.; SEVERIAN, D. Aglomerações industriais relevantes: o que dizem sobre as desigualdades regionais no Brasil. In: ENCONTRO NACIONAL DA ASSOCIAÇÁO NACIONAL DE PLANEJAMENTO URBANO E REGIONAL, 18., 2019, Natal, Rio Grande do Norte. Anais... Natal: Anpur, 2019.

MORCEIRO, P. C. A indústria brasileira no liminar do século XXI: uma análise de sua evolução estrutural, comercial e tecnológica. 2018. Tese (Doutorado) - Universidade de São Paulo, São Paulo, 2018.

NEGREIROS, R.; MONTEIRO NETO, A. Dossiê: paradigmas técnico-econômicos e reconfiguraçấo territorial. Revista Brasileira de Estudos Urbanos e Regionais, v. 21, n. 2, p. 223-240, maio-ago. 2019.

NEGRI, B. Concentração e desconcentraçáo industrial em Sáo Paulo (1880-1990). 1994. 280 f. Tese (Doutorado) - Universidade Estadual de Campinas, Campinas, 1994.

PACHECO, C. A. Novos padróes de localizaçáo industrial? Tendências recentes dos indicadores da produção e do investimento industrial. Brasília: Ipea, 1999. (Texto para Discussão, n. 633).

PEET, R. Relations of production and relocation of United States manufacturing industry since 1960. Economic Geography, v. 59, n. 2, p. 112-143, 1983.

PERROUZ, F. A economia do século XX. Lisboa: Livraria Morais, 1969.

PROENÇA, A. D. de A.; SANTOS JUNIOR, W. R. dos. Reestruturação produtiva e consolidação de novos eixos de desenvolvimento territorial: o caso do vetor de desenvolvimento perimetral da macrometrópole paulista. Revista Brasileira de Estudos Urbanos e Regionais, v. 21, n. 2, p. 312-328, maio-ago. 2019.

SABOIA, J. Desconcentração industrial no Brasil na década de 1990: um processo dinâmico e diferenciado regionalmente. Nova Economia, v. 11, n. 2, p. 85-121, 2001.

- Continuidade do processo de desconcentração regional da indústria brasileira nos anos 2000. Nova Economia, v. 23, n. 2, p. 219-278, 2013.

SARTI, F; HIRATUKA, C. Desempenho recente da indústria brasileira no contexto de mudanças estruturais domésticas e globais. Campinas: Editora Unicamp, 2017. (Texto para Discussão, n. 290). 
SILVA, S. Expansão cafeeira e as origens da indústria no Brasil. São Paulo: Alfa-Ômega, 1976.

SILVA, R. D. da; IRAZÁBAL-ZURITA, C. E. Boom, burst e doom: o complexo petroquímico do Rio de Janeiro como catalisador do desenvolvimento urbano-regional, Revista Brasileira de Estudos Urbanos e Regionais, v. 21, n. 2, p. 351-370, maio-ago. 2019.

STORPER, M. Economic development and the regional question in the third world: from import substitution to flexible production. London: Pion, 1991.

TOWNROE, P. M.; KEEN, D. Polarization reversal in the state of São Paulo. Regional Studies, v. 18, n. 1, p. 45-54, 1984.

VIEIRA, D. J. A guerra fiscal no Brasil: caracterização e análise das disputas interestaduais por investimento os em período recente, a partir das experiências de MG, BA, PR, PE e RJ. In: MONTEIRO NETO, A. (Org.). Governos estaduais no federalismo brasileiro: capacidades e limitaçóes governativas em debate. Brasília: Ipea, 2014.

\section{BIBLIOGRAFIA COMPLEMENTAR}

DINIZ, C. C.; VIEIRA, D. J. Ensino superior e desigualdades regionais: notas sobre a experiência recente do Brasil. Revista Paranaense de Desenvolvimento, v. 36, n. 129, p. 99-115, 2015.

MONTEIRO NETO, A.; SILVA, R. de O.; SEVERIAN, D. Perfil e dinâmica das desigualdades regionais no Brasil em territórios industriais relevantes. Brasília: Ipea, 2019. (Texto para Discussão, n. 2511).

MORCEIRO, P. C. Desindustrializaçáo na economia brasileira no período 2000-2011: abordagens e indicadores. São Paulo: Cultura Acadêmica, 2012. 


\section{ANEXO}

TABELA A.1

Evolução das aglomerações industriais relevantes (AIRs) com mais de 10 mil empregos industriais (2000, 2010, 2015 e 2018)

\begin{tabular}{|c|c|c|c|c|c|c|c|c|}
\hline Código & Microrregião & 2000 & $\begin{array}{l}\text { Crescimento } \\
(2000-2010)\end{array}$ & 2010 & $\begin{array}{l}\text { Crescimento } \\
(2010-2015)\end{array}$ & 2015 & $\begin{array}{l}\text { Crescimento } \\
(2015-2018)\end{array}$ & 2018 \\
\hline 13007 & Manaus & 49.230 & 119,8 & 108.206 & $-8,8$ & 98.732 & $-11,8$ & 87.036 \\
\hline 15007 & Belém & 23.327 & 27,8 & 29.820 & $-1,3$ & 29.447 & $-8,5$ & 26.935 \\
\hline 15017 & Paragominas & 10.695 & $-18,1$ & 8.755 & $-20,5$ & 6.958 & $-17,7$ & 5.727 \\
\hline 21002 & São Luís & 7.393 & 64,9 & 12.192 & $-5,0$ & 11.579 & $-5,7$ & 10.915 \\
\hline 22003 & Teresina & 13.087 & 51,4 & 19.810 & $-0,4$ & 19.729 & $-1,3$ & 19.465 \\
\hline 23005 & Sobral & 11.310 & 101,4 & 22.773 & $-12,4$ & 19.943 & $-6,8$ & 18.588 \\
\hline 23016 & Fortaleza & 93.261 & 54,4 & 144.034 & $-4,9$ & 137.022 & $-11,3$ & 121.590 \\
\hline 23017 & Pacajus & 5.651 & 243,4 & 19.406 & $-25,0$ & 14.554 & $-3,0$ & 14.123 \\
\hline 23032 & Cariri & 9.643 & 88,0 & 18.132 & $-5,5$ & 17.142 & $-18,8$ & 13.918 \\
\hline 24017 & Macaíba & 8.717 & 22,1 & 10.643 & $-4,8$ & 10.137 & $-22,8$ & 7.825 \\
\hline 24018 & Natal & 18.709 & 84,5 & 34.526 & $-31,0$ & 23.809 & $-6,0$ & 22.389 \\
\hline 25017 & Campina Grande & 11.163 & 78,6 & 19.938 & $-1,7$ & 19.603 & $-6,9$ & 18.254 \\
\hline 25022 & João Pessoa & 22.918 & 39,1 & 31.877 & 2,0 & 32.516 & $-15,0$ & 27.647 \\
\hline 26008 & Vale do Ipojuca & 8.811 & 136,8 & 20.865 & 6,9 & 22.312 & 0,5 & 22.419 \\
\hline 26013 & Goiana & 17.101 & 57,0 & 26.845 & 5,6 & 28.339 & 3,1 & 29.230 \\
\hline 26014 & Vitória de Santo Antão & 1.803 & 299,6 & 7.204 & 39,1 & 10.024 & 6,5 & 10.671 \\
\hline 26015 & Escada & 19.971 & 46,5 & 29.250 & $-40,2$ & 17.503 & $-9,1$ & 15.905 \\
\hline 26016 & Itamaracá & 7.078 & 64,0 & 11.611 & 3,8 & 12.049 & 1,9 & 12.280 \\
\hline 26017 & Recife & 53.110 & 28,6 & 68.276 & $-3,5$ & 65.865 & $-14,2$ & 56.483 \\
\hline 26018 & Suape & 8.023 & 146,0 & 19.739 & 21,8 & 24.045 & $-26,1$ & 17.781 \\
\hline 27009 & Mata Alagoana & 10.106 & 133,1 & 23.560 & $-43,6$ & 13.293 & $-22,4$ & 10.319 \\
\hline 27011 & Maceió & 19.589 & 42,7 & 27.945 & $-0,3$ & 27.851 & $-13,9$ & 23.982 \\
\hline 27012 & São Miguel dos Campos & 19.816 & 66,1 & 32.905 & $-38,5$ & 20.247 & $-15,9$ & 17.021 \\
\hline 28011 & Aracaju & 9.679 & 49,8 & 14.499 & 13,4 & 16.448 & $-8,4$ & 15.064 \\
\hline 29012 & Feira de Santana & 11.365 & 143,6 & 27.684 & 3,7 & 28.708 & 3,0 & 29.556 \\
\hline 29020 & Santo Antônio de Jesus & 2.895 & 280,3 & 11.010 & $-7,9$ & 10.141 & $-10,7$ & 9.053 \\
\hline 29021 & Salvador & 44.890 & 75,4 & 78.747 & 0,8 & 79.404 & $-9,5$ & 71.882 \\
\hline 29028 & Vitória da Conquista & 3.189 & 184,4 & 9.069 & 5,7 & 9.588 & 15,2 & 11.050 \\
\hline 29029 & Itapetinga & 4.870 & 299,4 & 19.450 & $-59,2$ & 7.935 & 3,8 & 8.234 \\
\hline 29031 & Ilhéus-Itabuna & 7.695 & 68,9 & 12.994 & $-15,6$ & 10.973 & $-3,4$ & 10.602 \\
\hline 29032 & Porto Seguro & 4.879 & 76,2 & 8.598 & 14,9 & 9.875 & 7,2 & 10.582 \\
\hline 31007 & Montes Claros & 9.783 & 5,5 & 10.325 & 25,6 & 12.968 & $-3,7$ & 12.487 \\
\hline 31018 & Uberlândia & 19.642 & 69,8 & 33.354 & $-13,1$ & 28.972 & 7,0 & 31.008 \\
\hline 31021 & Frutal & 3.122 & 158,0 & 8.055 & 39,2 & 11.213 & $-4,0$ & 10.759 \\
\hline 31022 & Uberaba & 10.954 & 73,2 & 18.967 & 13,5 & 21.534 & $-8,9$ & 19.621 \\
\hline
\end{tabular}




\begin{tabular}{|c|c|c|c|c|c|c|c|c|}
\hline Código & Microrregião & 2000 & $\begin{array}{l}\text { Crescimento } \\
(2000-2010)\end{array}$ & 2010 & $\begin{array}{l}\text { Crescimento } \\
(2010-2015)\end{array}$ & 2015 & $\begin{array}{l}\text { Crescimento } \\
\text { (2015-2018) }\end{array}$ & 2018 \\
\hline 31027 & Sete Lagoas & 15.508 & 63,7 & 25.386 & $-3,6$ & 24.472 & $-0,6$ & 24.325 \\
\hline 31030 & Belo Horizonte & 143.672 & 52,1 & 218.489 & $-13,3$ & 189.337 & $-10,2$ & 170.110 \\
\hline 31039 & Ipatinga & 21.794 & 70,4 & 37.133 & $-36,7$ & 23.514 & 3,2 & 24.268 \\
\hline 31043 & Divinópolis & 30.775 & 79,5 & 55.248 & $-7,2$ & 51.287 & 3,7 & 53.179 \\
\hline 31047 & Passos & 5.165 & 104,3 & 10.552 & $-26,8$ & 7.726 & $-9,0$ & 7.033 \\
\hline 31048 & São Sebastião do Paraíso & 6.920 & 129,8 & 15.899 & 2,3 & 16.257 & $-0,4$ & 16.191 \\
\hline 31050 & Varginha & 11.706 & 75,1 & 20.497 & 0,5 & 20.593 & $-8,9$ & 18.757 \\
\hline 31051 & Poços de Caldas & 15.020 & 37,8 & 20.695 & $-3,0$ & 20.082 & 1,6 & 20.399 \\
\hline 31052 & Pouso Alegre & 11.826 & 119,3 & 25.938 & 7,3 & 27.829 & 4,9 & 29.196 \\
\hline 31053 & Santa Rita do Sapucaí & 4.882 & 117,2 & 10.604 & 9,2 & 11.584 & $-9,2$ & 10.518 \\
\hline 31056 & Itajubá & 9.603 & 52,6 & 14.651 & $-19,0$ & 11.869 & $-7,6$ & 10.964 \\
\hline 31064 & Ubá & 14.224 & 102,8 & 28.845 & $-3,1$ & 27.952 & 1,8 & 28.447 \\
\hline 31065 & Juiz de Fora & 24.126 & 24,3 & 30.000 & $-5,3$ & 28.404 & $-4,9$ & 27.004 \\
\hline 31066 & Cataguases & 7.410 & 42,9 & 10.592 & $-20,3$ & 8.439 & $-12,3$ & 7.402 \\
\hline 32003 & Colatina & 8.072 & 25,1 & 10.098 & $-1,5$ & 9.943 & 2,1 & 9.730 \\
\hline 32006 & Linhares & 8.410 & 110,4 & 17.696 & 14,4 & 20.236 & $-3,6$ & 19.508 \\
\hline 32009 & Vitória & 32.088 & 47,0 & 47.172 & $-3,7$ & 45.441 & $-6,2$ & 42.602 \\
\hline 32012 & Cachoeiro de Itapemirim & 11.092 & 51,6 & 16.815 & 8,7 & 18.279 & $-12,3$ & 16.028 \\
\hline 33004 & Macaé & 2.918 & 233,8 & 9.740 & 8,0 & 10.521 & 2,2 & 10.753 \\
\hline 33005 & Três Rios & 5.097 & 66,2 & 8.473 & 20,2 & 10.186 & $-10,2$ & 9.150 \\
\hline 33007 & Nova Friburgo & 12.124 & 69,4 & 20.533 & $-14,6$ & 17.538 & $-2,5$ & 17.097 \\
\hline 33011 & Vale do Paraíba Fluminense & 23.823 & 54,9 & 36.901 & $-2,9$ & 35.826 & 12,5 & 40.298 \\
\hline 33015 & Serrana & 13.984 & 44,5 & 20.202 & $-12,5$ & 17.686 & $-14,3$ & 15.165 \\
\hline 33018 & Rio de Janeiro & 201.201 & 23,0 & 247.570 & $-9,2$ & 224.890 & $-22,4$ & 174.531 \\
\hline 35003 & Votuporanga & 6.670 & 59,3 & 10.623 & $-4,8$ & 10.117 & 2,5 & 10.374 \\
\hline 35004 & São José do Rio Preto & 25.827 & 97,2 & 50.918 & $-0,2$ & 50.835 & $-2,7$ & 49.448 \\
\hline 35005 & Catanduva & 7.434 & 121,8 & 16.490 & $-12,5$ & 14.424 & $-4,9$ & 13.716 \\
\hline 35010 & São Joaquim da Barra & 6.959 & 121,4 & 15.409 & 41,6 & 21.824 & 2,6 & 22.392 \\
\hline 35012 & Franca & 25.990 & 35,8 & 35.288 & $-11,4$ & 31.263 & $-11,2$ & 27.755 \\
\hline 35013 & Jaboticabal & 13.834 & 94,2 & 26.869 & $-0,4$ & 26.752 & $-5,3$ & 25.345 \\
\hline 35014 & Ribeirão Preto & 31.099 & 119,9 & 68.399 & $-7,6$ & 63.222 & $-2,5$ & 61.624 \\
\hline 35016 & Andradina & 2.964 & 192,7 & 8.677 & 19,2 & 10.347 & 1,1 & 10.461 \\
\hline 35017 & Araçatuba & 7.348 & 74,5 & 12.823 & 8,8 & 13.953 & $-4,1$ & 13.378 \\
\hline 35018 & Birigui & 24.808 & 22,6 & 30.423 & $-7,5$ & 28.152 & $-10,7$ & 25.131 \\
\hline 35019 & Lins & 7.195 & 127,7 & 16.381 & $-21,4$ & 12.883 & 5,2 & 13.547 \\
\hline 35020 & Bauru & 19.539 & 29,3 & 25.259 & $-1,1$ & 24.984 & $-6,4$ & 23.379 \\
\hline 35021 & Jaú & 21.815 & 86,7 & 40.729 & $-21,0$ & 32.177 & $-5,7$ & 30.354 \\
\hline 35023 & Botucatu & 7.992 & 95,1 & 15.596 & $-13,8$ & 13.450 & $-2,8$ & 13.077 \\
\hline 35024 & Araraquara & 19.947 & 124,6 & 44.794 & 8,7 & 48.669 & $-7,1$ & 45.200 \\
\hline
\end{tabular}


Texto para

Discussão

2640 Tendências Regionais da Indústria Brasileira no Século XXI

(Continuação)

\begin{tabular}{|c|c|c|c|c|c|c|c|c|}
\hline Código & Microrregião & 2000 & $\begin{array}{l}\text { Crescimento } \\
(2000-2010)\end{array}$ & 2010 & $\begin{array}{l}\text { Crescimento } \\
(2010-2015)\end{array}$ & 2015 & $\begin{array}{l}\text { Crescimento } \\
(2015-2018)\end{array}$ & 2018 \\
\hline 35025 & São Carlos & 19.360 & 24,7 & 24.134 & $-6,0$ & 22.680 & $-4,2$ & 21.737 \\
\hline 35026 & Rio Claro & 14.636 & 90,3 & 27.845 & $-8,5$ & 25.470 & $-2,6$ & 24.817 \\
\hline 35027 & Limeira & 38.392 & 65,2 & 63.421 & $-1,3$ & 62.601 & 0,3 & 62.773 \\
\hline 35028 & Piracicaba & 33.191 & 80,2 & 59.814 & $-4,7$ & 56.977 & 1,3 & 57.710 \\
\hline 35029 & Pirassununga & 10.208 & 24,1 & 12.664 & 3,7 & 13.130 & $-4,2$ & 12.579 \\
\hline 35030 & São João da Boa Vista & 15.845 & 60,2 & 25.383 & $-2,6$ & 24.715 & $-3,4$ & 23.886 \\
\hline 35031 & Moji Mirim & 23.256 & 60,0 & 37.212 & $-7,3$ & 34.501 & $-0,5$ & 34.344 \\
\hline 35032 & Campinas & 155.498 & 50,9 & 234.601 & $-6,6$ & 219.119 & $-4,7$ & 208.842 \\
\hline 35033 & Amparo & 10.961 & 55,0 & 16.993 & $-3,4$ & 16.408 & $-1,2$ & 16.207 \\
\hline 35036 & Presidente Prudente & 10.952 & 136,8 & 25.932 & $-4,3$ & 24.826 & $-8,9$ & 22.624 \\
\hline 35038 & Marília & 13.493 & 56,0 & 21.053 & $-1,8$ & 20.674 & $-0,9$ & 20.481 \\
\hline 35040 & Ourinhos & 9.764 & 84,7 & 18.033 & 2,2 & 18.424 & $-0,4$ & 18.358 \\
\hline 35042 & Itapetininga & 4.420 & 97,9 & 8.746 & 16,1 & 10.158 & $-5,7$ & 9.583 \\
\hline 35043 & Tatuí & 15.544 & 78,1 & 27.686 & 7,2 & 29.671 & $-3,7$ & 28.567 \\
\hline 35046 & Sorocaba & 79.584 & 54,5 & 122.974 & $-1,2$ & 121.498 & $-5,8$ & 114.401 \\
\hline 35047 & Jundiaí & 42.209 & 81,3 & 76.529 & $-5,4$ & 72.424 & $-4,3$ & 69.283 \\
\hline 35048 & Bragança Paulista & 21.939 & 107,3 & 45.483 & $-8,2$ & 41.732 & 5,9 & 44.215 \\
\hline 35050 & São José dos Campos & 77.909 & 31,3 & 102.261 & $-9,1$ & 92.909 & $-9,3$ & 84.263 \\
\hline 35051 & Guaratinguetá & 13.256 & 46,4 & 19.404 & $-6,7$ & 18.108 & $-1,0$ & 17.928 \\
\hline 35057 & Osasco & 70.270 & 40,7 & 98.893 & $-11,0$ & 88.005 & $-6,9$ & 81.910 \\
\hline 35058 & Franco da Rocha & 9.319 & 58,8 & 14.801 & $-19,3$ & 11.944 & 5,7 & 12.630 \\
\hline 35059 & Guarulhos & 86.069 & 42,7 & 122.789 & $-18,2$ & 100.471 & $-10,4$ & 89.982 \\
\hline 35060 & Itapecerica da Serra & 36.940 & 60,0 & 59.107 & $-11,1$ & 52.562 & $-9,5$ & 47.548 \\
\hline 35061 & São Paulo & 662.641 & 14,5 & 759.021 & $-19,9$ & 608.005 & $-16,9$ & 505.211 \\
\hline 35062 & Mogi das Cruzes & 50.812 & 38,6 & 70.435 & $-8,2$ & 64.678 & $-2,4$ & 63.147 \\
\hline 35063 & Santos & 17.058 & 27,1 & 21.679 & $-12,2$ & 19.037 & $-32,0$ & 12.945 \\
\hline 41001 & Paranavaí & 8.172 & 134,1 & 19.133 & 5,6 & 20.212 & $-7,2$ & 18.764 \\
\hline 41002 & Umuarama & 6.734 & 192,1 & 19.668 & $-2,1$ & 19.248 & $-23,8$ & 14.663 \\
\hline 41003 & Cianorte & 8.386 & 170,4 & 22.673 & $-0,3$ & 22.604 & $-4,6$ & 21.575 \\
\hline 41005 & Campo Mourão & 4.471 & 128,9 & 10.235 & $-7,5$ & 9.471 & 12,3 & 10.639 \\
\hline 41006 & Astorga & 5.585 & 219,9 & 17.867 & 4,1 & 18.594 & $-6,9$ & 17.320 \\
\hline 41009 & Maringá & 21.715 & 88,1 & 40.856 & 0,6 & 41.108 & $-1,6$ & 40.431 \\
\hline 41010 & Apucarana & 20.285 & 77,5 & 36.016 & $-6,8$ & 33.566 & $-0,9$ & 33.255 \\
\hline 41011 & Londrina & 30.455 & 57,5 & 47.957 & $-7,3$ & 44.475 & $-8,1$ & 40.861 \\
\hline 41019 & Telêmaco Borba & 4.337 & 73,0 & 7.503 & 39,4 & 10.456 & $-0,8$ & 10.372 \\
\hline 41021 & Ponta Grossa & 15.833 & 50,4 & 23.810 & 6,4 & 25.336 & $-3,4$ & 24.483 \\
\hline 41022 & Toledo & 13.343 & 132,1 & 30.964 & 7,5 & 33.273 & 1,7 & 33.853 \\
\hline 41023 & Cascavel-Paraná & 8.470 & 223,7 & 27.419 & 3,7 & 28.426 & 6,3 & 30.227 \\
\hline 41024 & Foz do Iguaçu & 5.989 & 129,5 & 13.743 & 40,0 & 19.242 & 3,6 & 19.941 \\
\hline
\end{tabular}


(Continuação)

\begin{tabular}{|c|c|c|c|c|c|c|c|c|}
\hline Código & Microrregião & 2000 & $\begin{array}{l}\text { Crescimento } \\
(2000-2010)\end{array}$ & 2010 & $\begin{array}{l}\text { Crescimento } \\
(2010-2015)\end{array}$ & 2015 & $\begin{array}{l}\text { Crescimento } \\
(2015-2018)\end{array}$ & 2018 \\
\hline 41026 & Francisco Beltrão & 7.599 & 117,4 & v16.523 & 12,7 & 18.624 & $-34,5$ & 12.201 \\
\hline 41027 & Pato Branco & 4.158 & 144,7 & 10.173 & 26,9 & 12.907 & 10,6 & 14.280 \\
\hline 41029 & Guarapuava & 10.982 & 3,7 & 11.384 & 10,8 & 12.618 & $-1,9$ & 12.380 \\
\hline 41037 & Curitiba & 122.351 & 61,1 & 197.118 & $-12,4$ & 172.629 & $-5,4$ & 163.325 \\
\hline 42001 & São Miguel do Oeste & 4.901 & 151,9 & 12.344 & 11,9 & 13.809 & 8,6 & 14.997 \\
\hline 42002 & Chapecó & 21.055 & 91,3 & 40.270 & 11,2 & 44.774 & 4,3 & 46.708 \\
\hline 42003 & Xanxerê & 6.207 & 65,3 & 10.261 & 20,4 & 12.355 & $-5,1$ & 11.722 \\
\hline 42004 & Joaçaba & 24.642 & 35,5 & 33.384 & 9,5 & 36.564 & 11,3 & 40.686 \\
\hline 42005 & Concórdia & 8.773 & 67,0 & 14.647 & 8,2 & 15.849 & 6,8 & 16.932 \\
\hline 42006 & Canoinhas & 10.372 & 22,7 & 12.730 & 9,3 & 13.912 & 23,5 & 17.184 \\
\hline 42007 & São Bento do Sul & 19.326 & 13,3 & 21.902 & 2,8 & 22.518 & 1,9 & 22.957 \\
\hline 42008 & Joinville & 76.925 & 69,7 & 130.571 & $-5,0$ & 124.061 & 2,3 & 126.894 \\
\hline 42010 & Campos de Lages & 9.923 & 27,6 & 12.665 & 9,7 & 13.892 & 1,8 & 14.139 \\
\hline 42011 & Rio do Sul & 18.320 & 62,7 & 29.806 & 6,1 & 31.632 & 2,9 & 32.542 \\
\hline 42012 & Blumenau & 82.377 & 62,7 & 134.034 & $-6,9$ & 124.790 & $-0,4$ & 124.272 \\
\hline 42013 & Itajaí & 11.720 & 118,4 & 25.596 & 31,1 & 33.556 & $-10,1$ & 30.169 \\
\hline 42015 & Tijucas & 5.378 & 168,7 & 14.448 & $-6,0$ & 13.575 & 6,1 & 14.402 \\
\hline 42016 & Florianópolis & 13.824 & 75,8 & 24.308 & 3,6 & 25.186 & 4,9 & 26.420 \\
\hline 42018 & Tubarão & 18.370 & 53,9 & 28.277 & 8,2 & 30.599 & 0,0 & 30.606 \\
\hline 42019 & Criciúma & 22.531 & 92,2 & 43.299 & 4,6 & 45.271 & $-3,4$ & 43.714 \\
\hline 42020 & Araranguá & 7.092 & 73,6 & 12.311 & 0,4 & 12.364 & $-12,5$ & 10.824 \\
\hline 43004 & Erechim & 11.276 & 49,8 & 16.896 & $-1,7$ & 16.603 & $-5,3$ & 15.719 \\
\hline 43008 & ljuí & 4.910 & 100,8 & 9.861 & 9,8 & 10.827 & $-5,8$ & 10.200 \\
\hline 43010 & Passo Fundo & 12.711 & 72,0 & 21.864 & $-0,5$ & 21.752 & $-1,2$ & 21.487 \\
\hline 43014 & Guaporé & 10.783 & 67,9 & 18.100 & 1,7 & 18.400 & $-6,4$ & 17.216 \\
\hline 43016 & Caxias do Sul & 88.293 & 60,7 & 141.859 & $-10,9$ & 126.418 & $-4,5$ & 120.778 \\
\hline 43020 & Santa Cruz do Sul & 17.336 & 17,3 & 20.339 & 7,4 & 21.840 & 3,0 & 22.488 \\
\hline 43021 & Lajeado-Estrela & 32.769 & 22,2 & 40.052 & 3,8 & 41.569 & $-1,8$ & 40.817 \\
\hline 43023 & Montenegro & 21.077 & 29,4 & 27.280 & 3,3 & 28.172 & 2,5 & 28.888 \\
\hline 43024 & Gramado-Canela & 46.191 & 21,4 & 56.058 & $-10,4$ & 50.230 & $-8,7$ & 45.863 \\
\hline 43026 & Porto Alegre & 186.451 & 21,5 & 226.531 & $-15,8$ & 190.764 & $-9,2$ & 173.145 \\
\hline 43027 & Osório & 6.760 & 39,1 & 9.400 & 9,1 & 10.257 & 1,9 & 10.456 \\
\hline 43033 & Pelotas & 11.010 & 9,1 & 12.007 & $-18,4$ & 9.796 & $-1,3$ & 9.669 \\
\hline 43035 & Litoral Lagunar & 4.092 & 52,6 & 6.243 & 142,2 & 15.121 & $-53,0$ & 7.109 \\
\hline 50004 & Campo Grande & 9.514 & 121,3 & 21.056 & $-4,5$ & 20.098 & 1,3 & 20.360 \\
\hline 50007 & Três Lagoas & 3.472 & 213,0 & 10.868 & $-2,1$ & 10.642 & 13,9 & 12.117 \\
\hline 50010 & Dourados & 7.370 & 180,9 & 20.705 & 15,6 & 23.925 & $-7,1$ & 22.237 \\
\hline 50011 & Iguatemi & 3.282 & 160,8 & 8.560 & 45,1 & 12.424 & $-0,2$ & 12.400 \\
\hline 51006 & Alto Teles Pires & 1.956 & 433,1 & 10.428 & 31,6 & 13.726 & $-8,1$ & 12.611 \\
\hline
\end{tabular}


Texto para

Discussão

2640 Tendências Regionais da Indústria Brasileira no Século XXI

\begin{tabular}{|c|c|c|c|c|c|c|c|c|}
\hline Código & Microrregião & 2000 & $\begin{array}{l}\text { Crescimento } \\
(2000-2010)\end{array}$ & 2010 & $\begin{array}{l}\text { Crescimento } \\
(2010-2015)\end{array}$ & 2015 & $\begin{array}{l}\text { Crescimento } \\
(2015-2018)\end{array}$ & 2018 \\
\hline 51007 & Sinop & 11.329 & $-28,4$ & 8.109 & $-12,6$ & 7.087 & 7,1 & 7.589 \\
\hline 51017 & Cuiabá & 11.694 & 101,6 & 23.580 & $-4,5$ & 22.520 & $-15,1$ & 19.123 \\
\hline 51021 & Rondonópolis & 3.436 & 165,0 & 9.104 & 25,5 & 11.427 & 0,6 & 11.501 \\
\hline 52007 & Anápolis & 14.669 & 118,7 & 32.074 & 23,6 & 39.648 & $-6,1$ & 37.235 \\
\hline 52010 & Goiânia & 52.882 & 50,3 & 79.492 & 6,2 & 84.382 & $-7,6$ & 77.980 \\
\hline 52012 & Entorno de Brasília & 4.075 & 118,7 & 8.910 & $-2,1$ & 8.721 & 14,9 & 10.023 \\
\hline 52013 & Sudoeste de Goiás & 6.084 & 297,4 & 24.178 & 9,6 & 26.500 & $-12,9$ & 23.094 \\
\hline 52015 & Meia Ponte & 5.081 & 136,9 & 12.039 & 39,7 & 16.816 & $-3,8$ & 16.170 \\
\hline 53001 & Brasília & 16.791 & 62,4 & 27.275 & 1,6 & 27.699 & $-6,2$ & 25.972 \\
\hline
\end{tabular}

Fonte: Emprego Formal da Indústria. Relação Anual de Informações Sociais (Rais), Secretaria Especial de Previdência e Trabalho. Ministério da Economia. Disponível em: $<$ http://www.rais.gov.br> 
Ipea - Instituto de Pesquisa Econômica Aplicada

Assessoria de Imprensa e Comunicação

\section{EDITORIAL}

\section{Coordenação}

Reginaldo da Silva Domingos

\section{Supervisão}

Carlos Henrique Santos Vianna

\section{Revisão}

Bruna Oliveira Ranquine da Rocha

Carlos Eduardo Gonçalves de Melo

Elaine Oliveira Couto

Lis Silva Hall

Mariana Silva de Lima

Marlon Magno Abreu de Carvalho

Vivian Barros Volotão Santos

Laysa Martins Barbosa Lima (estagiária)

\section{Editoração}

Aline Cristine Torres da Silva Martins

Mayana Mendes de Mattos

Mayara Barros da Mota (estagiária)

\section{Capa}

Danielle de Oliveira Ayres

Flaviane Dias de Sant'ana

\section{Projeto Gráfico}

Renato Rodrigues Bueno

The manuscripts in languages other than Portuguese published herein have not been proofread.

\section{Livraria Ipea}

SBS - Quadra 1 - Bloco J - Ed. BNDES, Térreo.

70076-900 - Brasília - DF

Fone: (61) 2026-5336

Correio eletrônico: livraria@ipea.gov.br 

Composto em adobe garamond pro 12/16 (texto) Frutiger 67 bold condensed (títulos, gráficos e tabelas) Rio de Janeiro-RJ 



\section{Missão do Ipea}

Aprimorar as políticas públicas essenciais ao desenvolvimento brasileiro por meio da produção e disseminação de conhecimentos e da assessoria ao Estado nas suas decisões estratégicas.

\section{MINISTÉRIO DA ECONOMIA}

ipea ipea

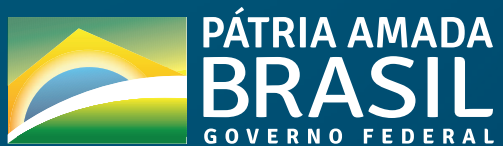

